IZA DP No. 6521

Land Use Rights, Market Transitions, and

Labor Policy Change in China (1980-4)

Yiu Por (Vincent) Chen

April 2012 


\title{
Land Use Rights, Market Transitions, and Labor Policy Change in China (1980-4)
}

\author{
Yiu Por (Vincent) Chen \\ University of Sheffield \\ and IZA
}

\section{Discussion Paper No. 6521 \\ April 2012}

\author{
IZA \\ P.O. Box 7240 \\ 53072 Bonn \\ Germany \\ Phone: +49-228-3894-0 \\ Fax: +49-228-3894-180 \\ E-mail: iza@iza.org
}

Any opinions expressed here are those of the author(s) and not those of IZA. Research published in this series may include views on policy, but the institute itself takes no institutional policy positions.

The Institute for the Study of Labor (IZA) in Bonn is a local and virtual international research center and a place of communication between science, politics and business. IZA is an independent nonprofit organization supported by Deutsche Post Foundation. The center is associated with the University of Bonn and offers a stimulating research environment through its international network, workshops and conferences, data service, project support, research visits and doctoral program. IZA engages in (i) original and internationally competitive research in all fields of labor economics, (ii) development of policy concepts, and (iii) dissemination of research results and concepts to the interested public.

IZA Discussion Papers often represent preliminary work and are circulated to encourage discussion. Citation of such a paper should account for its provisional character. A revised version may be available directly from the author. 
IZA Discussion Paper No. 6521

April 2012

\section{ABSTRACT \\ Land Use Rights, Market Transitions, and Labor Policy Change in China (1980-4)}

This paper provides a systematic analysis of the way shifts in property utilization rights in China induced another sequence of institutional changes that led to the rise of rural-urban labor migration from 1980 to 1984, a critical period in the country's market transition. I show that the 1980s' Household Responsibility System (HRS), which brought family farming back from the communal system, endowed rural households not only with land use rights, but also with de facto labor allocation rights. These shifts in property relations promoted a growth in agricultural market size as well as the emergence of intraprovincial non-hukou rural-urban migration, which may have made labor retention policies such as the small township strategy ineffective, and may have given the government an incentive to deregulate its subsequent labor market policy.

JEL Classification: J43, J61, R23, R52, R58

Keywords: rural-urban migration, labor mobility, undocumented labor, institutional change

Corresponding author:

Yiu Por (Vincent) Chen

The School of East Asian Studies

The University of Sheffield

Shearwood Road

Sheffield, S10 2TD

United Kingdom

E-mail: y.p.chen@sheffield.ac.uk 
"It makes little sense for economists to discuss the process of exchange without specifying the institutional setting within which trading takes place."

-R. Coase (1992, p. 718)

\section{1, Introduction}

Why did China have such a high degree of labor migration during the early 1980s, although the hukou system, a labor mobility restriction policy, was still in place? ${ }^{1}$ Why did the outcome of labor policies deviate so far from the central government's original plan? The question is why, if the Household Responsibility System (HRS) ${ }^{2}$ as a policy promotes rural productivity and stabilizes rural society, we witness the floating population rising an average of 1 million annually while household productivity increased rapidly during the $1980 \mathrm{~s} ?^{3}$ No persuasive story has been told about the emergence of undocumented labor migration and the "gradual reform" in labor policy over the reform period. This paper seeks to provide a systematic analysis of the institutional factors that explain the emergence of an urban labor market in contemporary China. It reveals that the wave of intraprovincial non-hukou rural-urban labor migration

\footnotetext{
${ }^{1}$ Established in the 1950s, the hukou system is known as a strict household registration system that requires migration approval for both origin and destination, subject to central quotas. The objective of this system is to restrict migration into urban (city and town) sectors, in particular, the city areas. The system is a mixture of welfare and the right to migrate; only hukou migrants would have had entitlement to a city's welfare and necessity assessments. In other words, it was impossible to migrate without changing to the urban hukouhukou status since no job would be found nor food provided from official supplies to any undocumented migrant. The "town" hukou is a kind of "urban" hukou; however, in reality, unlike the "city hukou," peasants usually do not really regard "town hukou" as "urban hukou" because its welfare and assessment of opportunity are not much different than in the villages; at least, they were not during the early reform period. For details of the hukou system and its evolutions, please see Cheng and Selden (1994).

${ }^{2}$ The HRS replaced the old "communal system" and redistributed a portion of the farmland to the peasants according to household unit. In return, the government obtained a certain amount of agricultural production with predetermined (low) prices as a tax collected from the peasants. The aim of this policy was to keep rural societies stable by assuring enough food and agricultural production. In this sense, the HRS is not a policy that releases mobility restriction. The HRS also changed the local cadres' labor mobility monitoring incentives. They once recorded rural labor income in communes using a system of work-points. Now, they do not need to check the participation of rural labor and assign work-points, but have shifted to collecting formal and informal rural taxation such as rural procurements and rural fees. In this regard, the HRS can indicate change in the political (monitoring) system after Mao's era. See Riskin (1987) for a detailed description of the operations of and transformations in this work-point system and the labor-monitoring system in communes; see also Perkins 1988, p. 607) for the original objective of the HRS.

3 "Non-hukou migrants" and "floating population" are terms for undocumented migrants who, without change of hukou registration status, had lived at the place of destination for no less than a year or had been absent from the place of household registration for more than a year in the 1982 and 1990 censuses. Furthermore, non-hukou migration has been rapidly emerging; their number increased from 11 million in the 1982 census to 18 million in the 1990 census (Liang, 2001, p. 503.). The 1987 census also revealed that 59.9 percent of non-hukou migrants were from rural areas. See also Chan, Liu, and Yang (1999, Table 1) for comparisons of characteristics of hukou and non-hukou rural-urban migrants.
} 
(hereafter, rural-urban migration) in China during the early 1980s is strongly correlated to the development of HRS. ${ }^{4}$

Theoretically, the transition from a rigid labor policy, with no labor mobility rights and no income rights in rural areas, to the development of a flexible labor policy is a remarkable institutional change. However, current research usually focuses on the direct implication of one institutional change for economic development. While this perspective can give a precise measure of the direct effect of an institutional change on economic development, we lack the theoretical perspective to look at a series of institutional changes. ${ }^{5}$ It may be important to understand the institutional changes from a system point of view; as Freeman (1993, pp. 407-408) remarks on the way labor markets and other institutional arrangements affect the performance of low-income countries, “... the 1980s developments and analysis suggest that the [labor] institutions and policies that unleash or restrain sustained growth differ across settings and periods ... we ought perhaps to explore the domains in which different institutional arrangements produce better results." To echo Freeman's argument, it may be useful to understand the chain reaction, from the change of land use rights institutions to non-hukou rural-urban migration, as one of the major forces in place during the transition of urban labor markets, and subsequent labor policy change in transition economies. The direct implications of failing to recognize the power of interconnections among institutional arrangement changes may result in distorted theoretical analysis and ineffective labor policy making.

Empirically, I use a seemingly uncorrelated regression model to estimate a system of respective impacts through three equations: an agricultural production function, an urban agricultural product market sales growth, and a non-hukou rural-urban migration growth. I show that the development of HRS was a major force that pushed reform of the urban agricultural product market and labor policy in China in the early1980s. In particular, I illustrate that the HRS could be regarded as a way to measure the intensity of decommunization (I call it an "index of decommunization" hereafter). I confirm that the HRS had a positive effect not only on urban agricultural product markets but also on intraprovincial non-hukou rural-urban migration, while another labor policy, the small township strategy, indexed by village collective output, did not have a negative effect on the dependent variables. That is, the HRS, as an index of the decommunization effect, together with the newly emerged urban market demands generated by urban individual labor sales, overcame the village collectives' reducing effects on non-hukou rural-urban migration and set the stage for migration dynamics during this early reform period. I then validate the claim using a Monte Carlo study to investigate different policy scenarios. The

\footnotetext{
${ }^{4}$ This study uses the term "intraprovincal non-hukou rural-urban migrant" to represent the intraprovincal non-hukou rural migrants to the city areas because migrating to towns is not generally attractive to rural migrants, as noted in footnote 1 . In addition, the number of intraprovincial non-hukou rural-urban migrants could be a good measure of undocumented rural labor migration to the city because this kind of migrant is usually the primary source of informal migration to cities within their provinces due to their greater geographical proximity. The hukou system was strictly controlled by the government during the early reform period, and only hukou migrants would have had entitlement to a city's welfare and necessity assessments.

${ }^{5}$ Certainly there are a large number of research findings showing the importance of institutions to economic development (e.g., Acemoglu, 2003, 2006; North, 1990; Williamson, 1996). However, many of these studies focused on the direct effect of one signal institutional change to economic development.
} 
paper proceeds as follows: I first develop a framework for understanding the household allocation of labor and labor market institutional change, and then I explore the labor policy evolutions of the early and mid 1980s. Next, I report an empirical study of the factors contributing to the institutional change, and finally, I discuss the policy implications after the conclusion at the end of the paper.

\section{2, Unlocking the Double Lock to Labor Mobility: Labor Mobility Policy Changes During the Early and Mid 1980s}

Since the 1950s, the labor mobility policy in China has worked like a double lock, with one end governed by the commune system in the rural areas and the other controlled by the hukou system and the related rationing system in the urban sectors. ${ }^{6}$ The HRS not only provided the incentives to change rural land use rights, but more importantly, served as an index of the decommunization that unlocked the labor allocation system on both sides. $^{7}$ In particular, before the HRS was initiated in 1980, communes in rural China controlled the allocation of rural labor, while the state-owned economy appropriated urban labor. ${ }^{8}$ Some early works have documented the development of the rural product market and labor market. ${ }^{9}$ The policy development and the institutional change are summarized in Table 1.

\section{[Table 1 about here]}

In 1980, the HRS changed property rights on land use and, more importantly, on labor force allocation, which led to the emergence of non-hukou rural-urban migration. The HRS system fundamentally shifted the relationship between the state and the peasant. Under the commune system, peasants gave most of their production to the state, according to the central plan. To compensate peasant households in a fair manner, the government had, early on, devised a point system to reward each peasant household with work-points for the services it provided to the collective production effort. One political consequence of this system was that village cadres were responsible for closely monitoring the labor effort of village households to assure that work-points were awarded fairly. With implementation of the HRS, however, the state no longer cared about the exact allocation of labor by individual households since it now wanted only the contracted amount of grain production from peasants. The political outcome of this

\footnotetext{
${ }^{6}$ See also Riskin (1987) for detailed descriptions of communes and the state-owned economy in China before the reform. Shue (1984) documented the change of communes in the early 1980s.

${ }^{7}$ Lin (1992, p. 37) mentioned that the development of the HRS was an unintended consequence in 1978 and that it was officially accepted by the central government while 45 percent of the production teams had already been dismantled.

${ }^{8}$ See the descriptions in footnote 2 for details.

${ }^{9}$ For the historical development of the rural product market, see Skinner (1964-65), Nee and Young (1991), and Nee and $\mathrm{Su}$ (1990), who put the development of rural product markets within the perspective of market transition theory. See also Sicular (1995) for the growth of trade and procurement policy changes in rural market fairs.
} 
shifting goal was that local village cadres were no longer required to monitor household labor contributions. Instead, they had only to ensure that households handed over the contracted amount of grain at the end of the year. De facto, then, the rural household gained autonomy and rights over the allocation of its labor, set the stage for space for the rapid development of goods and labor markets. With legalization of the rural product market and liberalization in labor allocation, rural markets soon spread to the cities.

Table 1, Row 3, shows the average HRS ratio. ${ }^{10}$ This growth ratio was extremely high from 1980 to 1984, during the first few years of legalization of the HRS. In the same period, the urban agricultural market grew substantially. ${ }^{11}$ The two effects together could make the rural-urban migrant sustainable in the urban areas.

Table 1, Row 4, reveals impressive growth in peasant sales to the urban population, an index of urban agricultural market growth. This rapid growth resulted from a 1984 policy shift that reduced the number of products under state quota purchase to only $30 .^{12}$ The agricultural products that were not absorbed by the state's agricultural procurement system were then channeled to the market fairs (Zhang, 2001, p. 258). At the same time, we also observed, the number of non-hukou migrants increased drastically. Table 1, Row 5, shows the growth in the number of non-hukou migrants, using the 5\% random sample of the 1\% Population Sample Survey (1987), which records the number of migrants from 1982 to $1986 .{ }^{13}$ The correlation between the two variables could be (1) that the number of migrant workers increased sharply as the HRS continued and more food became available for their purchase in urban areas, and (2) that they subsequently gained more mobility rights with the development of urban labor market transition and, hence, were able to challenge the hukou system. ${ }^{14}$

In May 1981, the central government tried to stop the non-hukou rural-urban migration by promoting a "small township strategy," which focused on small townships for local market development and surplus rural labor absorption. ${ }^{15}$ The early version of the small township strategy was a new state policy on migration. Peasants were permitted to "leave the land but not the village" (litu bu lixiang) and "leave the village without

\footnotetext{
${ }^{10}$ This is the yearly average of the provincial-level HRS ratio. The HRS ratio is the percentage of production teams that converted to the HRS system within each province. The figure shown in this column is different from the one shown in Lin (1992, Table 3, Column 1) because I use the provincial average from the data set provided by the China Center for Economic Research in electronic form, which was used in Lin's (1992) regression. However, this data is different from the figures reported in Lin (1992), Table 3, Column 1). Due to the lack of provincial-level HRS data for 1979-80, Lin used data reported from Economic Weekly News to fill in the 1979-81data. Also, the 1981-84 figures are extracted from China Agriculture Yearbooks rather than from the data set itself directly. Please see Lin (1992, Table 3) for data source details and Lin (1992, p. 49) for his discussions of the way he circumvented the HRS data problems. ${ }^{11}$ According to Lin (1992, Table 1), the overall agricultural growth rate between 1978 and 1984 is 7.7 percent annually, which is much higher than the 1952-78 growth, which was 2.9 percent annually, and 1984-87, which was 4.1 percent annually.

${ }^{12}$ The limited market fair in nearby townships was not allowed until the policy of self-sufficient peasants (zili kouliang hukou) extended to towns in 1983 (Perkins, 1990). See also Sicular (1995) on the growth of rural market fairs.

${ }^{13}$ The 1987 population census is the first census that documents the non-hukou migration from 1982 to 1986.

${ }^{14}$ Solinger (1999, pp. 48-49) noted that peasants began to make their way into towns. Zweig (1997, pp. 191) also reported that there were 1.3 million newly employed migrants during 1980 and that the central government began a campaign to send those migrant workers back to rural areas in 1981-82.

${ }^{15}$ For details of the strategy, please see State Council (1981).
} 
entering the city" (lixiang bu jincheng). ${ }^{16}$ This strategy was later regarded as ineffective due to the slow labor absorption rate of Township and Village Enterprises (TVEs) and the poor living conditions in small towns. ${ }^{17}$ Table 1 , Column 2, reveals a low labor absorption rate. In 1983, the inability of the original small township strategy to retain surplus rural labor in the nearby townships forced the central government to adopt a policy redefining "township" and encouraging the growth of towns. In the meantime, the central government officially allowed "self-sufficient households" (zili kouliang hukou) to move to towns. Peasants, in general, were not satisfied with small township policy benefits and continued to find work in cities.

In 1984, the central government allowed peasants to create self-sufficient households in townships and tried to extend the role of TVEs and to absorb surplus rural labor. ${ }^{18}$ Meanwhile, the government never stopped its effort to control the flow of migrant workers, this time by introducing the Temporary Residence Permit (Zanzhuzheng) and Resident Identity Card. It was the first time in communist Chinese history that the government acknowledged the legal existence of rural residents in urban settings by issuing them identification documents. ${ }^{19}$

Putting this historical development into our conceptual framework, when the communes change their function from a work-point to a tax extraction system, it means that the government changes its strategy from factor price manipulation to a revenue extraction mechanism. ${ }^{20}$ Thus, when a government uses the revenue extraction mechanism, it is more likely to encourage efficient investment (or at least it lacks an

\footnotetext{
${ }^{16}$ Fei Xiaotong, one of the advisors of early China's reform who specialized in rural development, advocated the policy (Fei, 1985). Peasants were "encouraged" to settle in townships with at least 200,000 inhabitants and "allowed" to live in cities with 200,000 to 500,000 inhabitants (Zweig, 1997, p. 193).

${ }^{17}$ In fact, the TVEs can be further decomposed into town collectives and village collectives, while towns are usually considered to be "urban" in government administrative structure.

${ }^{18}$ In March 1984, the State Council's mandate, Agricultural Department and China Communist Party Report on Communal and Production Team Enterprises, changed its name to Township and Village Enterprises (TVEs) and allowed some communal members to modify their cooperatives and become new TVE industries. The number of TVEs then grew substantially. However, the industrialization policy is highly biased toward coastal areas. See Perkins (1990, p. 91).

${ }_{19}$ In the No. 1 document of the Ministry of Public Security issued at July 1985 all migrants aged 16 or older who intended to live in urban areas for more than six months were asked to apply for the permit in their hometowns. Two months later, the Standing Committee of the National People's Congress approved "The Regulations on Resident Identity Card in the PRC." All rural migrants aged 16 or older were required to have the permit available for inspection by the police. However, this strategy did not stop the flow of labor migration for two reasons: (1) The administrative system of controlling labor mobility was extremely ineffective. (2) There was a lack of coordination between the cadres in the migrants' communities of origin and those in their communities of destination as well as among different units dealing with temporary migrants within the host communities. The departments responsible for these permits were more concerned with getting the application fee than with effectively controlling labor flow (Zhang, 2001, p. 258). However, temporary migrants did not have legal rights to migrate freely. Another significant rural-urban labor migration during the history of communist China occurred during the Great Leap Forward era, as noted by Riskin (1987); however, the officials during that period did not issue any legal documents to rural migrants.

${ }^{20}$ Factor price manipulation, topically functioning during the Central Planning Era, distorted the market prices of agricultural products as low-cost factors supporting industrialization. Also, the hukou system may have served the purpose of a political consolidation by mobility restriction. The shift to a revenue extraction mechanism does not mean that there would be a lump sum tax, which does not distort incentive; but at least it increased production, which was better than the situation in the Factor Price Manipulation Era.
} 
incentive to suppress investment). In this regard, the urban agricultural product and labor market transition induced by property rights changes provides an opportunity for Pareto improvement for every participant in the society. In other words, market transition increases the economic growth of a society, even with labor market regulation rigidity. The research related to the effects the of product markets development on labor market regulation is understudied yet the interlocking of product and labor markets is essential to transition economies. ${ }^{21}$ This kind of market transition is particularly important to countries that have underdeveloped product and labor markets along with labor market regulations that induce above-equilibrium wages and high unemployment. Focusing on the labor allocation actions of peasant households and their aggregate impact on the institutional change of non-hukou rural-urban migration and labor policy, I argue that China went through this institutional change during the early $1980 \mathrm{~s}^{22}$

\section{Hypotheses and Model Framework}

Given the historical development and the conceptual framework just described, I propose two hypotheses to analyze the forces driving institutional changes. These hypotheses specify a coevolved, incremental institutional change to explain the rise of an urban labor market. ${ }^{23}$

1. The HRS freed up household allocation of labor and generated agricultural growth. The commune system could no longer hold the flow of rural labor to urban areas.

2. Development of the HRS not only led to an increase in the size of urban agricultural markets but also facilitated emergence of the urban labor market for ruralurban migrants. The small township strategy, however, did not effectively retain labor in rural areas.

These hypotheses form a sequence of step-by-step, incremental institutional changes under the aggregation of a household annual-based labor allocation model. The following section elaborates my argument in detail.

\footnotetext{
${ }^{21}$ The relationships between product and labor markets are also the focus of labor economists as well as macroeconomists. For instant, see Nickell (1999) for a discussion of the impact of monopoly power of product markets on labor markets. Blanchard and Giavazzi (2000), however, are mostly concerned with "rent generation" by product markets and "rent distribution" by labor markets, under the assumption of monopolistic competition and general equilibrium. See also Freeman's (1993) discussions of orthodox economists' views on labor market institutions. Markets that are developing with incomplete price mechanisms do not generally concern these economists.

${ }^{22}$ There are criticisms of the "generalization" of the market transition theory that has been abstracted from concrete conditions and institutional environments to explain the shift of market allocation change (see Parish and Michelson, 1996, p. 1056; Walder, 1996, p. 1072). See also Oi (1999) for those patron-client relationships at the local level. Brandt et al. $(2002$, p. 96) argue that when quotas and agricultural land rents were reduced and when the accountability of leaders was increased in the early 1980s, land rental was able to be shifted from administrative allocation mechanisms to market mechanisms.

${ }^{23}$ I assume a static model with the contemporaneous relationship between a dependent variable and one or more independent variables. That is, I assume no autocorrelation in the causality relationships of these hypotheses, which is inferred from a usual peasant family's annual-based farming practice. Cases and evidence to support the claim of the existence of those relationships can be found in Chang and Kwok (1990, pp.152-55). I will, however, test the validity of this assumption in the next section.
} 


\subsection{Model Specifications}

From the hypotheses and framework just discussed, I specify three interrelated growth equations that depict the coevolution of the institutional changes.

\section{Agricultural Production Function}

An agricultural production function serves as the basis for the subsequent regression analysis. I assume a Cobb-Douglas agricultural production function. The unique feature of the model lies in the institutional variable "\% of HRS," which contributes to the growth of output through increasing incentive to produce and more flexibility in labor allocation. ${ }^{24}$ The "multiple cropping index" variable captures the distribution and intensity of effort in relation to cash crop output. I estimate the growth of crop output by the following equation: ${ }^{25}$

$\ln ($ Crop output it $)=\beta_{1}(\%$ of HRS it $)+\beta_{2} \ln ($ land it $)+\beta_{3} \ln ($ labor it $)+\beta_{4}$

$\ln ($ capital it $)+\beta_{5} \ln ($ fertilizer it $)+\beta_{6}$ (multiple cropping index it)

where $i$ denotes province $=\{1,2, \ldots, 28\}$

$t$ denotes year $=\{1980, \ldots, 1984\}$

\section{Urban Agricultural Product Market Growth}

To explain how agricultural production growth emerged, we need a record of the amount of equilibrium urban agricultural product market sales. I used "agricultural population sales to nonagricultural population," as the dependent variable to measure the growth of urban agricultural product market sales. The dependent variable refers to the agricultural goods sold by peasants to nonagricultural residents and public organizations in urban areas (Hsueh, Li, and Liu, 1993, p. 579). The values of "agricultural population sales to nonagricultural population" were recorded by urban local district administration committees for tax purposes; therefore, this variable can be a good measure of the size of an urban agricultural market. ${ }^{26}$ The reduced form equation of the equilibrium sales at the end of this section is my model to be estimated. ${ }^{27}$

To estimate how changes in the agricultural sector affected the equilibrium sales, I use supply side variables such as "agricultural population," "agricultural household

\footnotetext{
${ }^{24}$ Lin (1988) first estimated this production function with the "HRS ratio in the province." The difference between Lin's estimate and mine is that my model uses the 1980-84 data. The reason I used 1980-84 data is that 1980 is the first year to show the HRS ratio and 1984 is the year of almost completely implemented HRS.

${ }^{25}$ Taking the natural $\log$ of the original figures means estimating for the rate of change in the regression later, that is, growth rate of the dependent variables of interest. This method is applied to all the equations estimated here.

${ }^{26}$ Part of those sales were supplied and organized by rural supply and sales units of former rural communes. This information was also authenticated by Professor Nansheng Bai, of the Agricultural Research Unit, PRC, and Professor Fan Cai, of the Chinese Academy of Social Sciences, during my visit at the Chinese Academy of Social Sciences in 2001...

${ }^{27}$ The use of a reduced form equation means I assume that the supply and demand equation has been solved and that all explanatory variables are exogenous to the model. Both the urban agricultural product market sales and urban labor market equations here are assumed to be reduced form equations.
} 
dependent rate per rural laborer," "\% of HRS," "agricultural market price index," and "percentage of total area sown in nongrain crops." 28 This specification picks up the basic determinants of urban agricultural market growth. The "agricultural household dependent rate per rural laborer" variable can be used to measure the household burden, such as family consumption, that should have negative effects on the availability of agricultural surplus to sales. ${ }^{29}$ The HRS now captures the effect of relaxation of the labor allocation constraint on sales. ${ }^{30}$ In addition, the "multiple cropping index" not only captures the distribution and intensity of effort in relation to cash crop output, as shown in the last hypothesis; it can also represent the input mix that promotes growth in agricultural production. The "agricultural market price index" variable indicates whether the price system is functioning to affect sales in the rural areas. The "percentage of total area sown in nongrain crops" variable measures the ratio of nongrain crops to total agricultural sown acreage. For estimating urban demand effect on urban agricultural product market sales equilibrium, I used "nonagricultural population", "city average consumption", and "city consumer price index" as independent variables. The reduced form equation of urban agricultural product market sales is specified as follows:

$\ln ($ Urban agricultural product market sales it $)=\alpha_{1}(\%$ of HRS it $)+\alpha_{2}$ $\ln ($ agricultural population it $)+\alpha_{3} \ln \left(\right.$ agricultural household dependent it) $+\alpha_{4}$ (multiple cropping index it) $+\alpha_{5} \ln$ (agricultural market price index it) $+\alpha_{6}$ (percentage of total area sown in nongrain crops it) $+\alpha_{7} \ln$ (nonagricultural population it) $+\alpha_{8} \ln$ (city average consumption it) $+\alpha_{9} \ln ($ city consumer price index it)

\section{Intraprovincal Non-hukou Rural-urban Migration Growth}

To show how urban agricultural product market sales coevolved with the emergence of non-hukou rural-urban migration, I needed the records of non-hukou rural labor supply to the urban sector from 1980 to 1984. Similar to the records of HRS during its early implementation period, those records are not available for China from 1978 to 1981, so I used the intraprovincial "non-hukou rural-urban migrant number" from each province, which I aggregated from the 5\% random sample of China's 1\% Population Sample Survey (1987), to measure the non-hukou rural labor supply to the urban sector from 1982 to $1984 .^{31}$

\footnotetext{
${ }^{28}$ All variables are calculated in per 1,000 unit, with these exceptions: the price index for 1980 equals 100 , the agricultural household dependent rate per rural labor force is calculated per unit, and the percentage of total area sown in nongrain crops is calculated in percentage. Please see the data description in Appendix 1 for further details of data definitions and measures.

${ }^{29}$ Until 1985 , around $40 \%$ of agricultural output in rural China was for self-consumption in rural China. (Zhou, 1994, p. 463).

${ }^{30} \mathrm{Cook}(1999)$ asks whether rural households retain labor that is surplus to their requirements and how the existence of this surplus affects their labor allocation decisions. Rural households are in general dependent on a variety of activities and income sources for their livelihoods. Diversification among activities provides some protection against risk, so that the ability to transfer labor out of agriculture into higher-paying activities is an important determinant of household economic security.

${ }^{31}$ The census documented individual respondents' mobility from 1982 to 1986 . This data set is the first nationwide survey on individual workers' mobility that used hukou information. The 1982 census does not contain information on the workers' hukou status. This situation is similar to the HRS variable that Lin (1988) used. The HRS has emerged since 1978; however, it was illegal at the beginning, and the
} 
The reduced form equation of non-hukou rural-urban migration equilibrium is estimated by two sets of variables.

The rural labor supply to the urban sector is specified by the rural and agricultural factors: The " $\%$ of HRS" variable in this model is used to measure the institutional effect on releasing rural labor force from rural institutional constraints, as an index of decommunization. The variable "growth of rural labor" (weighted by a 3-year moving average of crop share) captures the substitution effect of rural labor supply; the increases in rural labor participation in the cropping sector will reduce the rural-urban migration. In addition, where cultivated land area increases, migration may decrease because the opportunity exists for potential migrants to generate higher income from agricultural activities. The variable "ratio of rural household dependent" is used to measure the pressure on a rural worker to migrate, given the family's agricultural land size that controlled in the regression; that is, a higher dependent ratio may induce a worker to migrate in order to generate adequate income for the family. Similarly, the growth of "agricultural CPI" relates to rural inflation rate, which may induce a peasant to migrate for better income. ${ }^{32}$

The urban demand for migrant labor can be represented by the following urban variables: the growth in "nonagricultural population" and "city consumer price index" may positively relate to the demand for rural labor. The "growth of Individual labor sales amount" is included to see how Individual labor sales induce more laborers to migrate. The "city consumer price index" is included to examine the question of whether the growth of migrant labor responds to urban price change. My hypothesis is that if the nonhukou migration is really induced by the relaxation of HRS but is not attracted by the urban planned economy sectors, we shall see no significant effect of urban formal sectors on the migration flow. To test this hypothesis, the growth of "total social output" is used to measure the aggregated provincial wealth effect from all sectors, including planned and unplanned economies as a whole, on growth of non-hukou rural-urban migrant labor.

To investigate further the composition of sectors that might have induced nonhukou rural-urban migration, this paper furthers the analysis by decomposing the total social output into several dimensions. It can be further decomposed into the following two classifications: by ownership and by industrial category; that is, the social output can be subdivided into the following ownership variables: "growth in state-owned industry output," "growth in township collective industry output," "growth in village collective industry output," and "growth in individual labor sales." The "growth in township collective industry output" and the "growth in village collective industry output" are indices of the small township strategy, and are used to examine the way the rural collective can absorb rural labor and reduce the number of rural workers going into the

documentation of HRS changes is from 1980, two years later (Lin, Cai, and Li, 1996, p. 132). Although earlier information has been truncated, the HRS analyses in Lin's works were not affected. Similarly, in our case, even though the 1987 census documented only the earliest migration history, up to 1982, from our reading of China's migration history, it appears that the non-hukou migrant population from 1980 to 1981 might be very small in number because 1980 was the year when the HRS started to be implemented on a national scale; therefore, at that time most peasants were transiting to the adoption of the change in HRS property rights. Relying on this fact, I assume non-hukou migration in 1980 and 1981 to be zero.

${ }^{32}$ All variables are in per 1,000 unit, with these exceptions: the price index for 1980, which equals 100 , the $\ln$ [land (per 1,000 mu)/ labor (per 1,000)], and the \% HRS, which is in percentage. Please see the data description in Appendix 1 for further details on data measures of the production-function-related variables. 
urban labor market. In order to show that the non-hukou migrants were largely responding to the newly emerged urban free labor market demand, I use urban individual labor sales as an indicator at the right-hand side of the regression. ${ }^{33}$ The variable "urban Individual labor sales amount" measures the self-employed laborers in urban sectors who engage in production work individually, own the means of production and products (or income), and have registered and received "individual business operation licenses" (Getihu) from the industrial/commercial administrative management department (Hsueh et al., 1993, p. 567). ${ }^{34}$

Furthermore, "state-owned industry output" can also be subdivided into three industrial sectors: "growth in light industrial output," "growth in heavy industrial output," and "growth in commercial sales." This paper compares the "total social outputs" with the other two sets of decomposed variables to disentangle their effects on non-hukou rural-urban migration.

The baseline reduced form equation for non-hukou rural-urban migration growth is specified as follows:

$\ln ($ Non-hukou rural-urban migration it $)=\gamma_{1}(\%$ of HRS it $)+\gamma_{2} \ln ($ labor it $)+\gamma_{3}$ $\ln ($ land $i t)+\gamma_{4} \ln ($ ratio of rural household dependent it $)+\gamma_{5} \ln ($ agricultural CPI it $)+\gamma_{6}$ $\ln \left(\right.$ nonagricultural population it) $+\gamma_{7} \ln$ (city consumer price index it) $+\gamma_{8} \ln ($ social total output it)

Two alternative decompositions of $\ln$ (social total output it) at the extended equation at Table 4, Columns 2 and 3, follow:

(1) $\ln ($ State-owned industry output it) $+\ln ($ township collective industry output it) $+\ln ($ village collective output it) $+\ln ($ urban Individual labor sales amount it)

(2) $+\ln ($ light industrial output it $)+\ln ($ heavy industrial output it $)+$

$+\ln ($ township collective industry output it $)+\ln ($ village collective output it $)+$ $\ln$ (urban Individual labor sales amount it)

Since the urban demand specification of this non-hukou rural-urban migration growth equation is one of the highlights of the analysis, I will compare the three versions of specification in the SURE estimation result section and assess their effects on each of the estimated market equilibrium outcome.

\footnotetext{
${ }^{33}$ Before the 1985 urban reform, with the tight urban employment rules and monitoring by street authorities and policemen under the hukou system, this form of ownership was the only one that officially allowed businesses to employ up to eight laborers (including the owner) with no need to report or register their labor identity. See also Chang and Kwok (1990) for information about some early one-day trip workers and construction workers during the mid 1980s in Hangzhou and Beijing, respectively. Christiansen (1992, p. 78) documented the policy origin and observed the illegal employment of migrant workers in Nanjing.

34، The individual labor sales at urban sector' measures the urban free labor market demand for rural labor, in addition to other urban workers ((Department of Training and Employment, Ministry of Labor and Social Security of the PRC, 2002, p. 3). In this document, the ministry acknowledged that this policy provided an important source of labor for the emerging urban labor market.
} 


\section{Data Source and Methodology}

The three data sets used in this analysis are officially published by the State Statistical Bureau. The first data set is related to agricultural variables in the production function. These variables are extracted from the official agricultural yearbooks from various years and supplied by Professor Justin Lin of the China Center for Economic Research (CCER). Variables in the agricultural production function have been used and published in Lin (1988). ${ }^{35}$ The second data set is related to the urban variables and farm sales from the agricultural to the nonagricultural populations. This information is extracted from Hsueh et al. (1993), who gathered data from the State Statistical Bureau's Chinese data source and compiled this English version of the historical data book. ${ }^{36}$ The third data set is a 5\% random sample of China's 1\% Population Sample Survey (1987). This census, done using hierarchical random sampling, is regarded as one of the most reliable individual-level demographic data sources to cover the entire country. It is also the first census that documented the non-hukou rural-urban migration from 1982 to 1986; therefore, it can be used to validate the claim of the hypothesis. In addition, this study also uses the historical rural industrialization and rural dependent ratio data generated from the Rural Soci-economic Investigation Team, State Statistical Bureau (2000).

\subsection{Methodology and Model Selection}

I use a set of seemingly uncorrelated regression (SURE) to estimate the market equilibrium outcomes specified above. This method allows for the correlations of error terms among equations, and I also define these correlations over time as a process of "coevolution" of these equations' market equilibrium paths. ${ }^{37}$

There are two estimation problems: a market equilibrium identification problem and an equilibrium coevolution problem. The first problem is identification of the urban market fairs' equilibrium sales volume that resulted from rural supply for urban demand. We need a demand function to identify the equilibrium sales volume, even when we are dealing with a distorted market ${ }^{38}$ (Kennedy, 1998, ch. 10). I put the set of "rural supply" and the set of "urban demand" variables into the reduced form equations, the urban agricultural product market and non-hukou rural-urban migration growth equation, in order to verify the related hypothesis as shown in last section. Note that the equilibrium

\footnotetext{
${ }^{35}$ I gratefully acknowledge Professor Justin Lin's generosity in providing his data used in Lin (1992).

${ }^{36}$ This historical data book is considered to be a standard reference for China's early economic development. Information from the book has been used by numerous authors of Chinese economic research as well as international organizations such as the World Bank.

${ }^{37}$ That is, all observed values in these equations are market-clearing values. Notice that "market clearing" does not mean that the market is free since the market is constrained by some institutional factors such as the HRS. See also Appendix 2 for the general specification of the SURE.

${ }^{38}$ As Professor Jano Kornai, in his transitional economics class at Harvard, once said, "Communist countries' central planning system distorted the market, but it is still a market." So, if we can find and put institutional variables in the right context, we can capture the dynamics of the captioned market development discourses.
} 
we observe is a market-coop-institutional equilibrium. ${ }^{39}$

As for the second problem, an omitted variable bias may be committed when running those equilibrium equations separately with the ordinary least squares (OLS) method, even though those regressions comprise a fixed effects model. ${ }^{40}$ The usual solution to the endogenous problems is to use the instrumental variable (IV) two-stage least squares, or Heckman, procedure. However, the power of the approach is limited when the sample size is small (Kennedy, 1998, p. 256). I have also performed the test of endogeneity for these equations, using Davidson and MacKinnon's (1993) augmented regression test (DWH test), and found no obvious evidence of the problem among the equations. However, I still find statistically significant correlations among the error terms of those equations, after running a generalized least squares estimation. ${ }^{41}$ This finding fits my conjecture that these three equilibrium equations may be correlated in their error terms. ${ }^{42}$ And due to their time sequence, one can easily establish a sequence of causality of the equations.

As all variables specified in the model are contemporary, one may question whether we can construct a dynamic panel analysis instead. I would, however, have concerns about the convergence problem in dynamic panel data for such a short time period. ${ }^{43}$ The problem is that if we want to have an autoregression that captures the autocorrelation in error terms, we may have a small-sample bias in the dynamic panel data estimators (Judson and Owen, 1996). In this regard, given the short time period panel ( $\leq 5$ years), one possible solution is to use the fixed effects model with no dynamic structure. Indeed, the problem of a short time period panel is that we do not have enough information to make sure that the error distribution is a first-order Martingale difference sequence. One weakness of the contemporary OLS regression that was presented here is that the autocorrelation in independent variables, such as growth in agricultural capital, is high, as mentioned in Lin (1992). I also found that the error term is highly autocorrelated. This means that although the coefficient may not be biased, $t$ statistics may not be valid. The advantage of seemingly uncorrelated regression is that it fits the model with feasible

\footnotetext{
${ }^{39}$ Demand functions here are aggregate proxies since no specific prices of those goods could be identified in the price indexes. That is, performance of this analysis requires an equilibrium price to pin down the equilibrium output on both demand and supply functions. However, due to the limitations of data sets, we don't have any price on both supply and demand functions other than those found in the price indexes. In other words, those supply and demand factors are, in fact, composed according to the substitutional and complementary effects of other variables in each reduced form of market equilibrium equations.

${ }^{40}$ One may question use of the reduced form equations to assume away the endogenous variables problem.

${ }^{41} \mathrm{~A}$ Ramsey regression specification error test has shown the possibility of this correlation problem. This test amounts to testing $y=x b+z t+u$ and then testing $t=0$. Powers of the fitted values are used for $z$.

${ }^{42}$ The error's correlations of agricultural growth with agricultural product sales growth and with non-hukou rural-urban migration growth are .34 and .07 , respectively. This means that, while agricultural growth correlates very strongly with agricultural sales growth, it does not correlate with non-hukou migration. However, agricultural sales growth has a quite strong correlation (.21) with non-hukou migration; this finding is consistent with the institutional evolution hypotheses that agricultural growth is correlated with agricultural sales growth and that agricultural sales growth is then correlated with non-hukou migration. A Breusch-Pagan test shows that the null hypothesis of no correlation among those equations is rejected at $p=$ 0 and $\chi^{2}(3)=20.90$.

${ }^{43}$ The period of my analysis is from 1980 to 1984 . The year 1985 is considered problematic in China's agricultural history. On the one hand, the grain procurement policy changed due to the limited absorption rate of the state agency, and on the other hand, the above-quota price also changed. See also the detailed history from Nong Ye Bu (1999).
} 
generalized least squares (FGLS) regression, which can account for the autocorrelations (Greene, 1997, pp. 687-89). In addition, I have used the average government procurement price as an agricultural price trend to tackle this problem. However, for the most part, fixed effects models with groupwise heteroskedasticity cannot be efficiently estimated with OLS. Fortunately, heteroskedastic models are usually fitted with FGLS.

In order to make sure that these regressions are estimated consistently, I use a small sample adjustment method to control for the potential problem of the small sample bias. ${ }^{44}$ Furthermore, I have estimated the regressions with random effects, regional fixed effects, and regional fixed effects with Government agricultural procurement price trend models, respectively. The Hausman specification test shows significant systematic differences between the random effects model and the one-way fixed effects model, but no systematic difference between the last two models. I will use the regional fixed effects with Government agricultural procurement price trend effects model as the basis for analysis. ${ }^{45}$

\footnotetext{
${ }^{44}$ The small sample adjustment is an alternate divisor in computing the covariance matrix for the equation errors. Instead of using the sample size $(n)$, the divisor is now taken to be square $\left[\left(t k_{i}\right) *\left(t k_{j}\right)\right]$ where $k_{i}$ and $k_{j}$ represent the number of parameters in equations $i$ and $j$, respectively.

${ }^{45}$ In any case, the two-way fixed effects model is usually deployed in statistical analysis and is regarded as a more robust analysis than the random effects model in terms of the result, because the two-way fixed effects model takes into account the individual effect and time effects. However, given the limitation of observation, inclusion of the full set of provincial dummies will drastically reduce the degree of freedom of the captioned regressions and reduce the power of tests. There is no statistical justification for using a unit level incremental time effect except technological improvement, since the use of a time trend will measure the common shock that is faced by provinces. To deal with the problem in a meaningful way, I use the yearly government average procurement price as a price lead trend, because this price trend is fit into the agricultural setting instead of the arbitrarily unit-level time dummies. To reduce the use of provincial dummies and give dummies a more meaningful measure, I have ranked provinces by per capita social output in 1980 and grouped them into seven groups of four. (Please see Appendix 3.)
} 


\section{Results}

Three market equilibriums will be estimated in this section. For each of them, I will show the estimated results of three reduced form urban demand functions of nonhukou migration growth equation as specified at the section 3.1; they are "Aggregated Social output," "SOE, Collectives, Individual labor output," and "Disaggregated Industrial Outputs," respectively, at Column 1, 2, 3 of Table 2-3 in this section.

\section{Agricultural Production Function}

[Table 2 about here]

Table 2 shows the production function. Similar to the result in Lin (1992), I find that, as the usual production function postulates, growth in the amount of land, labor, capital, and fertilizer can lead to agricultural growth. My result is very close to Lin's (1992) estimate; see Table 2 in this paper and Lin (1992, Table 5) for detailed comparison. The Wald test done after the regression also confirmed the hypothesis that the coefficients in the Cobb-Douglas production function are homogeneous to degree $1 .^{46}$ Two observations are worth mentioning here. First, the HRS ratio in provinces, as an institutional variable, is important in explaining growth in agricultural output. It is consistent with the most important finding in Lin (1992), that HRS has relaxed land rights and induced agricultural productivity. ${ }^{47}$ Second, the result is very consistent across different specifications of urban demand of non-hukou migration equation and robust in coefficients when the findings in the second and third columns are compared. ${ }^{48}$

\section{Urban Agricultural Product Market Growth}

[Table 3 about here]

Table 3 shows that the growth of urban agricultural produce market sales (agricultural population sales to nonagricultural populations) is positively affected by the growth of both the agricultural population and the HRS. This suggests that (1) provinces with larger agricultural population growth should develop urban agricultural markets faster, and (2) higher HRS growth induces more urban agricultural product market sales. These are reasonable conclusions since the larger the HRS, the more agricultural surplus

\footnotetext{
${ }^{46}$ Lin (1992, p. 35) also noticed the source and the potential problem of strong multicollinearity in the estimated production function. He then applied an alternative approach to estimate the production function. ${ }^{47}$ Lin (1992, p. 45) shows that the HRS contributes 19.8 percent to the growth in crop output, the highest proportion of all the inputs.

${ }^{48}$ The correlation between the labor variable and the economic geographical dummies may cause this variable to change. The fixed effects model is arguably more robust because these dummy variables would partition the correlations between explanatory variables and geographical effects.
} 
is available to sell and the more labor is available to foster these markets, as shown in Table 2. Even though the coefficient is small and insignificant, the agricultural household dependent rate per rural laborer shows a negative relationship to urban agricultural product market sales. This result is justifiable since, with other input factors remaining constant, an increase in the number of agricultural household dependents may lead to a decrease in agricultural sales, because agricultural household consumption may tend to be greater in rural areas. ${ }^{49}$

The agricultural price index does not appear to be statistically persuasive in explaining the growth of urban agricultural product market sales. This suggests that one characteristic of the urban agricultural product market - observed equilibrium quantitymay respond, not to the "official" agricultural market price, but to the growth of the city consumer price index. The "growth of the nonagricultural population" and the "city average consumption" also positively correlate with the dependent variable but not significantly. This may be because the city consumer price index represents the rise in the city consumption price and is much more persuasive in explaining the growth of the urban agricultural product market than is the agricultural price index. To summarize this analysis, I find that growth of urban agricultural product market sales is pushed by the growth of the HRS and pulled by the city consumer price index. ${ }^{50}$

\section{Non-hukou Rural-urban Migration Growth}

[Table 4 about here]

Table 4 gives a picture of non-hukou rural-urban migration growth, which resembles an informal urban labor market development. I first examine the general pattern of the model. Except for the growth of the HRS and of rural labor, almost all agricultural variables, as labor supply-side variables, are shown to be unimportant in explaining the growth of non-hukou rural-urban migrant labor. ${ }^{51}$ It is not surprising to see that growth of the number of agricultural labor reduces the non-hukou rural-urban migration because the substitution effects that increase the number of laborers participating in the farming activities will reduce the level of rural-urban migration.

In terms of the urban demand, the "total social output," which measures the aggregated outputs of all sectors at urban sectors, has a positively significant effect for rural-urban migration, as shown in Table 4, Column 1. However, when comparing this result with the decomposed urban demand at Table 4, Columns 2 and 3, excluding all other "official" urban demand variables from the planned economy show no statistical explanatory power over non-hukou migration. The non-hukou migrants' lack of response

\footnotetext{
${ }^{49}$ Until 1985, around 40 percent of agricultural output in rural China was for self-consumption in rural China (Zhou,1994, p. 463).

${ }^{50} \mathrm{~A}$ survey in Henan province also found that labor migration was induced by the demand side of the market. That is, individuals best suited to the types of employment available tend to migrate regardless of household labor supply or other factors that might predict labor productivity at home (Hare, 1999).

${ }^{51}$ Indeed, the government procurement price was increasing from 1978 to 1985 . There were also weather problems in 1985. See Zhou (1994, p. 425).
} 
to the planned economy variables is reasonable because China's reform started in rural areas and the urban SOE reform was not focused on the allocation of price and resources, including labor, until 1985; furthermore, even the SOE opened up the labor market later, with priority given to urban hukou citizens (Lau, Qian, and Roland. 2000, pp. 135-42; Lin et al., 1996, pp. 146-49). ${ }^{52}$ On the contrary, the urban individual labor sales growth shows a very positively significant effect on the growth of the number of non-hukou rural-urban migrant laborers. In this regard, it is logical to infer that non-hukou labor migration was induced largely by the development of urban individual labor economy which grew outside the planned economy at the urban sector during the early reform period.

Another important observation is that "township collective industrial output growth" and the "village collective industrial output growth" are important variables for understanding the effectiveness of the "small township strategy." If the small township strategy is effective at holding back non-hukou rural-urban migration, both variables should show significant negative effects on the dependent variables at Table 4, Columns 2 and 3. However, "village collective industrial output growth" shows only insignificant negative relations with non-hukou labor migration growth. This insignificant coefficient implies that the government's small township strategy at the village level was relatively unsuccessful at holding back labor that would have otherwise gone to the cities. Even worse is "township collective industrial output growth," which shows a positively relate to rural-urban migration. This means that the township collective growth did facilitate the non-hukou migration. Why was this so? The reason behind this finding may be because of the township welfare. In reality, peasants usually do not regard a town as "urban." See also, Kirby (1985, pp. 233-37). Even peasants who were granted "town hukou" status did not find this type o fhukou very attractive as it did not provide them any real benefit similar to that enjoyed by people who were real urban hukou residents. Some of them even regarded it as a "fake urban hukou" (Cheng and Selden, 1994). ${ }^{53}$ Therefore, it is reasonable that people in the non-hukou migration would not eventually land at the townships but would regard township TVEs as "bridges" to their dream places, namely, cities. $^{54}$ On the contrary, the HRS has been shown to have a very strong, robust positive effect on urban labor growth. ${ }^{55}$

Combining these two observations, one can easily infer, first, that the growth of non-hukou rural-urban migrant labor is "pushed" by the development of the HRS, and

\footnotetext{
${ }^{52}$ The first phase of the planned economy reform, 1978-84, was mainly focused on the enterprises' autonomy and their right to allocate part of their profit; that is, after the firms fulfilled the state target, they are entitled to sell their goods in markets. At the time of the first phase, many material markets were also developed. The second phase of SOE reform, started in 1985 [QUERY: As meant?]emphasized reduction in the planned allocation in raw materials. See also the historical development of the reform from Lin et al. (1996).

${ }^{53}$ See Kirby (1985, pp. 233-37) and Wong and Huen (1998, p. 975).

${ }^{54}$ Indeed, if we include the rural-town non-hukou migrant in the regression, we will see an even more significant impact to rural-urban migration. This result is part of the robustness check, which has not shown in this paper due to limited space; however, it can be obtained from the author upon request.

${ }^{55}$ Liang, Chen, and Gu, (2002), using the 1990 China Population Census with a robust logit model on migration decision, has shown that rural industrialization does not have a statistically persuasive impact on the probability of either intra- or interprovincial migration. In sum, the HRS effect not only offsets the rural industrialization effect but also successfully promotes the growth of rural labor migration to the urban sector.
} 
second, that the market for urban individual labor is arguably "informal" since no official index can capture the growth. ${ }^{56}$

\subsection{Robustness Check of the Proxies and Model Implications}

My robustness check addresses two issues. The first concerns the validity of the correlation between non-hukou migration and the urban labor market development out of the planned economy, in the regression models. The second pertains to the effectiveness of the central government's rural industrialization, the small township strategy, in restraining labor mobility and to the way the HRS contributed to labor mobility and counteracted the effect of rural industrialization policies.

\section{How was non-hukou migration related to urban labor market development during the early reform period?}

To validate the relationship between non-hukou migration and urban labor market development, I present a summary table to demonstrate the rank correlation by province between the number of non-hukou migrants and the number of individual labor, an index of urban labor market development, using the 5\% sample of the 1\% 1987 China Census.

Table 5 shows the provinces' relative rank on variables of interest. The names of the provinces are listed on the left. In Column 1, I list, in descending order, the number of non-hukou intraprovincial migrants, I compare Column 1's correlation to the descending ranking of urban individual laborers with the variable record of the number of individual laborers in urban markets.

[Table 5 about here]

Table 5, Column 2, gives the descending rankings of the provinces' number of individual urban labor in 1984 and shows the high correlation of these rankings with the information in Column 1. That is, 8 out of the top 10 urban individual provinces in Column 1 are also in the top 10 in Column 2. The rank correlation of the two variables is very high- 62 . The match of those variables helps validate the claim that non-hukou migration is correlated to the development of the urban labor market.

The other problem that warrants discussion is the measurement error of the dependent variables. As has been argued by econometricians, a measurement error that is on the left-hand side will not bias the estimation. However, the precision of the estimation certainly will be affected by the noise. The noise will then be determined empirically by the model and residual.

\footnotetext{
${ }^{56} \mathrm{~A}$ number of robustness checks have been conducted to confirm that the results are robust against different specifications. For example, I have also tried including the intraprovincial rural-town non-hukou migrant numbers as the dependent variable. All the results mentioned in the text hold. These robustness check tables can be obtained from the author upon request.
} 


\section{Did Rural Industrialization Reduce Migration Effectively During the 1980-84 Period?}

Due to the limitations of the panel data set and its short time period, we may not be able to fully explore the relationships of variables in the model in some hypothetical situations such as controlling for the growth rate of certain independent variables to examine their impacts on the dependent variables. I develop a Monte Carlo simulation to provide three different scenarios of the growth of individual labor. ${ }^{57}$

[Figure 1 about here]

Figure 1 shows three scenarios of the changing effect of the HRS on the growth of non-hukou migration while assuming other variables to be equal to their mean values. The first scenario shown in the figure is the mean growth rate; the growth rate is rather steep, taking the expected provincial average value of non-hukou migrant labor from 1,747 to 30,000 , more than 170 times the original size. ${ }^{58}$

Figure 1 also reveals the heterogeneity of the non-hukou migration supply from different provincial groups. The upper and lower curves of the figure show the dynamics of the poorest and the richest provincial groups, respectively, when the $\%$ of HRS ranges from 0 to 100 , holding other variables at their means. When $\%$ of HRS $=0$, the expected provincial average number of non-hukou migrants is only 57.4 and 998 for the richest and the poorest provincial groups, respectively; the average number of non-hukou migrant at poorest provincial group is over 17 times higher than the richest provincial groups when $\mathrm{HRS}=0$. When HRS reached $100 \%$ in 1984 , the richest provincial group expected average non-hukou migrant turns to be 25,500, while the poorest provincial group jumped to 160,000 . In addition, the growth rate in the poorest provincial group has been steep along with the HRS increases from 998 to 160,000 , a 160 times increment. In sum, the HRS successfully pushed the development of the non-hukou migration. Also, the poorest province's non-hukou migration growth has been much faster than that of the richest province, which is consistent with the historical fact.

To show the tension between the two contending variables-HRS and village collective industrial output impacts on non-hukou labor migration - I have developed two different scenarios based on the highest and the lowest village collective industrial output. $^{59}$ Figure 2 shows the growth of the number of non-hukou migrants when the value of the industrial output of village collective changed from the minimum to the maximum value during the 1980-84 period, while holding HRS at 0 and at 1 .

\footnotetext{
${ }^{57}$ The important feature of the Monte Carlo method is to eliminate estimation uncertainty, by assuming the law of large numbers. For a lucid delineation of the Monte Carlo method and its usage, please see King, Tomz, and Wittenberg (2000).

${ }^{58}$ Please note that because I use the $5 \%$ random sample of the $1 \%$ Population Survey for the non-hukou rural-urban migrant number, the value estimated will not be measured directly as the actual figure of the labor in the market. However, this study focuses on comparing the proportional change of resulting expected values of the migrant growth from different scenarios.

${ }^{59}$ The lowest $\ln$ (village collective industrial output): 10.62 . The highest $\ln$ (village collective industrial output): 15.98 .
} 
[Figure 2 about here]

The upper line on Figure 2 is the average effect of $\mathrm{HRS}=1$, and the second line is the highest $95 \%$ confidence interval (CI) of the non-hukou migrant growth curve when $\mathrm{HRS}=0$, all other variables hold at mean values. At the initial stage, when the village collective industrial output is at its lowest value, the HRS $=1$ curve's non-hukou migrant number $(207,377)$ is much higher than the CI's upper bound $=95 \%$ curve does $(76,699)$. Although the numbers at both curves are reduced as the village industrialization output increases, even when the village output value is at its maximum, the average migrant number of HRS $=1$ is still 5,435, which is almost double the value of the $95 \%$ CI upper bound, 2,827 .

In addition, if we compare the estimated mean number of non-hukou migrant of $\mathrm{HRS}=0$ and $\mathrm{HRS}=1$, the difference will be even larger. That is , at HRS $=0$, the estimated mean number of migrant labor when village collective industrial output is at its minimum and maximum values are 10,722 and 410, respectively; they are 18.3 times and 12.2 times lower than the respective average values when HRS $=1$. Putting the two observations together, they all suggest that HRS increases the level of non-hukou migration by relaxing labor allocation rights. Even assuming that the village industrial output is statistically persuasive at reducing the growth of urban individual labor, the reduction effect is smaller than the effect of HRS.

To recap, Table 1, Rows 1 and 2, present evidence for the slow growth and slow labor absorption of the early rural collectives. Even at a glance, one can see in Columns 1-2 that growth rates of TVE and TVE employee number are much lower than in row 5-the growth rate of of the peasants' sales to the urban population and the size of the non-hukou rural-urban migration. This result is consistent with another work of Liang, Chen, and $\mathrm{Gu}$ (2002), using the 1990 China Population Census with a robust logistics model on migration decision, showed that rural industrialization does not have a statistically persuasive impact on the probability of either intra- or interprovincial migration. In sum, the HRS effect not only offsets the rural industrialization effect but also successfully promotes the growth of individual labor in the urban sector. 


\section{Conclusion and Discussion}

In this paper, I have argued that the rise of non-hukou intraprovincial rural-urban migration in China was a stepwise institutional change led by peasants' household labor allocation, taking advantage of development of the HRS and market transitions from planned to free markets. Development of the labor market from planned to free made rural labor retention policies, such as the commune system and the small township strategy, ineffective at stopping the flow of rural labor to urban areas.

Empirically, I have modeled the coevolution of institutional change into a sequence of market transitions that started with the growth of agricultural output, which in turn, led to the development of urban agricultural product markets, and finally, to the growth of intraprovincal rural-urban non-hukou migration. I have shown, first, that the growth of HRS plays a significant role in agricultural growth. Second, not only does the HRS effect represent the relaxation of agricultural productivity but it is also a measure of flexibility of labor allocation by household. Third, I find statistical evidence to support the hypothesis that the HRS's role in releasing labor allocation rights is stronger than the absorption rate of rural industrialization, the most important measure of small township strategy to absorb rural labor.

To further our understanding of the two contending policy variables, namely, the HRS and village collective industrial output to intraprovincal rural-urban non-hukou migration, I further developed a Monte Carlo simulation to deduce some scenarios of different policy impacts. I found that growth of the HRS generally supported the development of non-hukou rural-urban migration. A reconfirmation of the analysis in this paper is that the HRS had very strongly positive effects on the development of urban labor markets, while they "washed out" the rural industrialization (negative) during the period of my analysis.

As has been shown in this paper, this process has, in fact, evolved toward the relaxation of rights, that is, each step of institutional change has granted more rights to peasants. Specifically, the initial granting of their rights to allocate their own labor grew into their receiving additional rights to sell their agricultural products in urban agricultural product markets and to work in urban sectors. As a result, a Pareto improving market development has emerged.

Other research on the dual-track system in China during the same period has also demonstrated a Pareto improvement during the reform. ${ }^{60}$ This is particularly important for developing countries because this approach gives the involved agents incentive to improve on the institutions for further market development. Consider the case of China. Given the high unemployment in the urban sector and surplus labor in the rural area, it was politically impossible to deregulate the protected labor market at the beginning of the reform. ${ }^{61}$ As the market transition pushed the macroinstitutional change forward, the labor market reform represented a step-by-step institutional development without much opposition. It enabled the urban sector consumer to enjoy goods and services at lower

\footnotetext{
${ }^{60} \mathrm{Lau}$ et al. (2000) developed a model to analyze the dual-track system. They claimed that the simultaneous liberalization of the market acts like a lump sum transfer to victims of the reform, while improving the efficiency of the whole market.

${ }^{61} \mathrm{Cai}$ (2001a) documented the nonexistence of the labor market before reform, the protection of urban residents, and the labor market regulation's tensions.
} 
prices and the rural migrant worker to earn higher wages and have more employment opportunities than were available in rural areas. In general, for countries with incomplete market and labor market regulations, the development of product and labor markets can be a solution to the problem of achieving a smooth transition during labor market deregulation.

Meanwhile, as the labor and product sales transactions continue to grow larger and trade develops, the security of property rights is important if there is to be incentive development and investment. ${ }^{62}$ China's rural laborers have been increasingly successful in getting more labor rights in a stepwise manner throughout the market process. ${ }^{63}$ The challenge that remains is to answer the following question: While the urban interest is still politically important and biased policies that favor urban resident are still enforced, how can the central government effectively balance rural and urban interests? While urban residents may contest the policies that grant rights to rural residents allowing them to migrate to urban areas, the central government may need to stress continually, to the nation as a whole, the potential problems of the nation's social instability and the need for long-term improvement of its welfare. ${ }^{64}$

\footnotetext{
${ }^{62}$ Little, Mazumdar, and Page (1987) documented the development of small manufacturing enterprises in India and suggested that intervention such as financial incentives can foster the development of those firms. Moreover, the newly emerged economic institutions may be so vulnerable that, without proper legal protection and upward mobility, some areas with high concentrations of undocumented migrant workers might eventually turn into slums.

${ }^{63}$ Solinger (1999) describes it as a struggle for citizenship. For the history of labor regulations and the relaxation of job restrictions in major cities in China, see Cai (2001b, p. 80). The job restrictions for rural non-hukou migrant in urban China only started to loosen since 2001.

${ }^{64}$ A survey by Knight, Song, and Jia (1999) shows that the government has successfully implemented its general policies of severely restricting permanent urban settlement of rural people and ensuring preferential access to urban jobs for urban residents. Their evidence indicates that government at various levels also restricts the employment of "floating" migrants by imposing fees and controls on enterprises and by erecting a labyrinthine system of permissions and fees through which rural migrants must pass. The authors also suggest that there is a danger that the policy of assisting and controlling labor flows will be subverted by opportunistic behavior.
} 


\section{References}

Acemoglu, D. (2006). 'A simple model of inefficient institutions', The Scandinavian Journal of Economics, 108(4), pp. 515-46.

Acemoglu, D. (2003). 'Why not a political Coase theorem? Social conflict, commitment, and politics', Journal of Comparative Economics, 31, pp. 620-52.

Blanchard, O. and Giavazzi, F. (2000). 'Macroeconomic effects of regulation and deregulation in goods and labor markets', Working Paper No. 01/02, January, Department of Economics, Massachusetts Institute of Technology.

Brandt, L., Huang, J., Li, G. and Rozelle, S. (2002). 'Land rights in rural China: Facts, fictions and issues'. The China Journal, 47, pp. 67-97.

Cai, F. (2001a). 'Employment situation and forecast: An analysis of the labor market emergence' (in Chinese), Working Paper Series 8, March, Chinese Academy of Social Sciences, Center of Human Resource Studies.

Cai, F. (ed.) (2001b) Chinese Population Mobility Forms and Channels (1990-1999) (in Chinese), Beijing: Chinese Social Science Documentation Press.

Chan, K. W., Liu, T., and Yang Y. (1999). 'Hukou and non-hukou migrations in China: Comparisons and contrasts', International Journal of Population Geography, 5, pp. 42548.

Chang, S.-D., and Kwok, R. Y.-W. (1990). 'The urbanization of rural China', in Kwok, R. Y.W. and Parish, W. L. (eds.), Chinese Urban Reform: What Model Now? Armonk, N.Y.: M. E. Sharpe, Inc., pp. 140-57.

Cheng, T. and Selden, M. (1994). 'The origins and social consequences of China's hukou system', The China Quarterly, 139, pp. 644-68.

Christiansen, F. (1992). "“Market transition” in China: The case of the Jiangsu labor market, 1978-1990', Modern China, 18(1), pp. 72-93.

Coase, R. (1992).. "The Institutional Structure of Production.” The American Economic Review 82(4), pp. 713-719.

Cook, S. (1999). 'Surplus labour and productivity in Chinese agriculture: Evidence from household survey data', Journal of Development Studies, 35(3), pp. 16-44.

Davidson, R. and McKinnon, J. G. (1993). Estimation and Inference Econometrics. Oxford: Oxford University Press. 
Department of Training and Employment, Ministry of Labor and Social Security of the PRC. (2002). "Skills Training in the Informal Sector in China." Paper presented at the $90^{\text {th }}$ International Labour Conference (ILC) in Geneva in June 2002.

Fei, X. T. (1985). 'Xiahao zhongguo renkou wenti zheipangqi [Play well the chess game of China's population issue]', in Zhongguo Renkou Liudong taishi Yu guanli [Trends and Management of China's Population Mobility] (in Chinese), Ji, D. S. and Shao, Q. (eds.), Beijing: Zhongguo Renkou Chubanshe.

Freeman, R. (1993). 'Labor market and institutions in economic development', American Economic Review, 83(2), pp. 403-8.

Gongjia Tongji Ju Nongcun Shehuijinji Diaocha Dui [Rural Socio-economic Investigation Team, State Statistical Bureau] (2000) Shin Zhonggong Wushinian Nongye Tongji Zhiliao. Zhongong Tongji ChuBan [The New China 50 Years Agricultural Statistical Information. China Statistical Press].

Greene, W. H. (1997). Econometric Analysis, 3rd edition, Upper Saddle River, N.J.: PrenticeHall International.

Hare, D. (1999). “Push" versus "pull” factors in migration outflows and returns: Determinants of migration status and spell duration among China's rural population', Journal of Development Studies, 35(3), pp. 45-73.

Hsueh, T.-T, Li, Q., and Liu, S. (eds.) (1993). China’s Provincial Statistics 1949-1989, Boulder, Colo.: Westview Press.

Judson, R. A. and Owen, A. L. (1996) 'Estimating dynamic panel models: A practical guide for macroeconomists', Federal Reserve Board of Governors mimeo.

Kennedy, P. (1998). A Guide to Econometrics, Cambridge, Mass.: MIT Press.

King, G, Tomz, M., and Wittenberg, J. (2000). 'Making the most of statistical analyses: Improving interpretation and presentation', American Journal of Political Science, 44(2), pp. 341-55.

Kirby, R. J. R. (1985). Urbanization in China: Town and Country in a Developing Economy 1949-2000, London: Croom Helm.

Knight, J., Song, L., and Jia, H. (1999) 'Chinese rural migrants in urban enterprises: Three perspectives', Journal of Development Studies, 35(3), pp. 73-104.

Lau, L. J., Qian, Y., and Roland, G. (2000). 'Reform without losers: An interpretation of China's dual-track approach to transition', Journal of Political Economy, 108(1), pp. 120-43. 
Liang, Z. (2001) "The age of migration in China." Population and Development Review, 27: 499-524..

Liang, Z., Chen, Y. P., and Gu, Y. (2002). 'Rural industrialization and internal migration in China', Urban Studies, 39(12), pp. 2175-87.

Liang, Z. and White, M. J. (1996). 'Internal migration in China, 1950-1988', Demography 33(3), pp. 375-84.

Lin, J. Y. (1988). 'The Household Responsibility System in China's agricultural reform: A theoretical and empirical study', Economic Development and Cultural Change, 36(3), pp. S199-S224.

Lin, J. Y. (1992). 'Rural reforms and agricultural growth in China', The American Economic Review, 82(March), pp. 34-51.

Lin, J. Y., Cai, F., and Li, Z. (1996). The China miracle: Development strategy and economic reform, Hong Kong: Chinese University Press.

Little, I. M. D., Mazumdar, D., and Page. J. M. (1987). Small Manufacturing Enterprises: A Comparative Analysis of India and Other Economies, New York: Oxford University Press, for the World Bank.

Nee, V. and Su, S. (1990). 'Institutional change and economic growth in China: The view from the villages', The Journal of Asian Studies, 49(1), pp. 3-25.

Nee, V. and Young. F. W. (1991). 'Peasant entrepreneurs in China's "Second Economy": An institutional analysis', Economic Development and Cultural Change, 39(2), pp. 293-310.

Nickell, S. (1999). 'Product markets and labour markets', Labor Economics, 6, pp. 1-20.

Nong Ye Bu Chan Ye Zhen Ce Yu Fa Gui Si [Agricultural Law and Policy Division], (ed.) (1999). Zhong Guo Nong Cun Wu Shi Nian [Fifty Years in China's Villages] (in Chinese), Beijing: Zhong Yuan Nong Ming Chu Ban She (Chinese Peasant Press).

North, D. C. (1990) Institutions, Institutional Change, and Economic Performance, Cambridge: Cambridge University Press.

Oi, J. C. (1999). Rural China Takes Off: Institutional Foundations of Economic Reform, Berkeley, Calif:: University of California Press.

Parish, W. L. and Michelson, E. (1996). 'Politics and markets: Dual transformations', American Journal of Sociology, 101(4), pp. 1042-59. 
Perkins, D. H. (1990) 'The influence of economic reforms on China's urbanization', in Kwok, R. Y.-W. and Parish, W. L. (eds.), Chinese Urban Reform: What Model Now? Armonk, N.Y.: M. E. Sharpe, Inc., pp. 78-106.

Perkins, D. H. (1988) “Reforming China's economic system.” Journal of Economic Literature, 26(2), pp. 601-45.

Riskin, C. (1987). China's Political Economy: The Quest for Development Since 1949, New York: Oxford University Press.

Shue, V. (1984). 'The fate of the commune', Modern China, 10(3), pp. 259-83.

Sicular T. (1995). 'Redefining State, Plan and Market: China's reforms in agricultural commerce', The China Quarterly, 144, pp. 1020-46.

Skinner W. G. (1964-65). 'Marketing and social structure in rural China: Parts I-III', Journal of Asian Studies, Part I, November 1964, 24(1), pp. 3-43; Part II, February 1965, 24(2), pp. 195-228; Part III, May 1965, 24(3), pp. 363-99.

Solinger, D. (1999). Contesting Citizenship, Berkeley, Calif.: University of California Press.

Walder, A. G. (1996). 'Markets and inequality in transitional economics: Toward testable theories', American Journal of Sociology, 101(4), pp. 1060-73.

Williamson, O. E. (1996). The Mechanisms of Governance, New York: Oxford University Press.

Wong, L. and Huen, W.-P. (1998). 'Reforming the household registration system: A preliminary glimpse of the blue chop household registration system in Shanghai and Shenzhen', International Migration Review, 32(4), pp. 974-94.

Zhang, G. (ed.) ( 2001). Rural Reform in China. Shenzhen: Hai Tian Publishing House.

Zhou, Q. R. (ed.) (1994). Rural Change and China Development, 1978-1989, vols. I-II (in Chinese), Hong Kong: Oxford University Press.

Zweig, D. (1997). Freeing China's Farmers: Rural Restructuring in the Reform Era, Armonk, N.Y.: M. E. Sharpe, Inc. 


\section{Appendix 1: Data Source and Data Descriptions}

\section{Data complied or estimated by Lin (1992, pp. 48-50):}

Gross Value of Crops: This is calculated from the gross physical output of seven cash crops (rice, wheat, corn, potatoes, sorghum, millet, and soybeans) and 12 cash crops (cotton, peanuts, rapeseed, sesame, jute, ramie, sugar cane, sugar beets, tobacco, tussah silk cocoons, mulberry silk cocoons, and tea), using the official 1980 prices as weights for aggregation.

Land (Cultivated): The data on cultivated land was provided by the State Statistical Bureau.

Labor Force in the Cropping Sector: This data was extracted from agricultural yearbooks and from information received from the State Statistical Bureau. The farm labor force includes those working in cropping, animal husbandry, forestry, fisheries, and sideline production. To obtain the estimate of the labor force in the cropping sector, I weighted the farm labor forces by the value share of crop output in total agricultural output.

Capital (Tractors and draft animals): This data was extracted from agricultural yearbooks and from information received from the State Statistical Bureau. It is measured by the horsepower of tractors and draft animals. To convert these numbers into horsepower, I used the weights recommended by the State Statistical Bureau.

Chemical Fertilizer: This data refers to the gross weight of fertilizer consumed and is taken from the agricultural yearbooks.

Changes in Farming Institutions: These changes were measured by the ratio of production teams in each province that hand converted to the HRS by the end of each year.

Index of State Above-Quota Prices Relative to Input Prices: Both prices were provided by the State Statistical Bureau and set to $1978=100$.

Index of Market Price (Agricultural market price index): This is a weighted average of prices for crops, livestock, and other products sold in rural free markets, provided by the State Statistical Bureau. This information contains some measurement errors, as a proxy for the market prices of crops may reduce the estimated effect that changes in market price have on growth in cash crops.

Percentage of Area Devoted to Nongrain Crops: This is a percentage obtained by dividing the sown acreage of nongrain crops by the total sown agricultural acreage.

Multiple Cropping Index: This is an index obtained by dividing the total sown agricultural area by the cultivated land area in each province. 
Data complied or estimated by Hsueh et al. (1993):

Agricultural Household Dependents: This is the average number of dependents per rural labor force extracted from the Chinese version of the agricultural yearbook.

Agricultural Population Sales to Nonagricultural Population (Sales by peasants to nonagricultural residents): This refers to the consumer goods sold by peasants to nonagricultural hukou residents' public organizations inside or outside country fairs (p. 579).

Agricultural Population: This refers to the total population in the area under the county (xian), excluding towns (p. 568).

Urban Individual Labor (Self-employed laborers in urban sectors): This refers to laborers in cities and towns who engage in production work individually; own the means of production, the products (or income), and registration; and receive "individual business operation licenses" from the Industrial/Commercial Administrative Management Department (p. 567).

City Average Consumption (Nonrural residents' consumption): According to China's present statistical system, consumption per resident is divided into four components: self-sufficient consumption; commodity consumption; consumption of cultural services; and consumption of personal housing, water, and electricity. According to the Public Security Department, people whose domiciles are registered as nonfarming are classified as nonrural residents (pp. 559-60).

City Consumer Price Index (Urban retail price index): This reflects the price level changes of consumer goods purchased in the market. In calculating the retail price index, a weighted arithmetic mean formula is used. The weights used are adjusted once a year according to the household survey data. About 285 commodities sold in the cities were chosen for calculation of the index, and 195 cities were selected as the basic units for data collection in 1987 (p. 582).

Nonagricultural Population: This refers to the total population in the area under the jurisdiction of a city or a town (p. 568).

Social Total Output (Gross domestic product): This refers to the total value of goods and services produced for final use by local and foreign residents in a certain period of time within a region (p. 551).

State-owned industrial output (Gross output value of state-owned industry): This refers to the total output value produced by industrial enterprises in which the means of production and the products or the incomes are owned by the state. It includes the total output of state-owned industries operated by central or regional government institutions, enterprises, etc (p. 572).

Heavy industrial output (Gross output value of heavy industry): Heavy industry produces the means of production and, therefore, provides various sectors of the national economy with the necessary materials and techniques. Depending on the nature of production and uses of products, heavy industry consists of the following three branches: Mining and lumbering industry, Raw materials industry, and Processing industry (for further details, please see pp. 572-73).

Light industrial output (Gross output value of light industry): Light industry is defined as industry that mainly produces consumer goods and handwork tools. 
Depending on the materials used, two types can be identified: industries using farm products as raw materials and those using nonfarm products as raw materials (for further details, please see pp. 572-73).

Urban Individual labor sales (Total value of retail sales of commodities produced by self-employed workers): Included are retail sales by workers in selfemployed commerce, the catering industry, and handicrafts via a business license issued by the industrial commercial administration departments (pp. 579).

Construction industrial output (Gross output value of construction): This refers to the total output value of construction and installation completed by construction and installation enterprises or units within a certain period (p. 548).

Transportation industrial output (Gross output value of transport, post, and telecommunications): This includes revenues from freight traffic, pipeline transport, loading and unloading services, agency services (not including revenue from passenger traffic, related supplementary production, and other business) as well as revenues of post and telecommunications services (p. 548).

Commercial sales (Total value of retail sales of consumer goods): This refers to the total value of consumer goods sold (1) directly to urban and rural residents for personal consumption, (2) to social groups for collective consumption, and (3) for other consumption for nonproductive purposes. However, sales of consumer goods among peasants are excluded (p. 577).

\section{Data extracted from the New China 50 Years Agricultural Statistical Information Gongjia Tongji Ju Nongcun Shehuijinji Diaocha Dui [Rural Socio- economic Investigation Team, State Statistical Bureau] (2000):}

Rural dependent ratio (Number of dependents per rural laborer): This refers to the provincial average of each household's total number of family members/number of workers in each province.

Town-Owned Collective Industrial Output (Gross output value of collectiveowned industry): This refers to the total output value of industrial enterprises where the means of production and the products or the incomes are owned by the (town) collectives.

Village-Owned Collective Industrial Output (Gross output value of collective-owned industry): This refers to the total output value of industrial enterprises where the means of production and the products or the incomes are owned by the (village) collectives. 


\section{Appendix 2: General Specification of the SURE Model}

Consider a more general specification of the model:

$Y_{i t}=X_{i t} \beta_{i}+\varepsilon_{i t}(i=1,2, \ldots, N ; t=1,2, \ldots, T)$.

Let $Y_{i}$ be the dependent variables of the three equilibrium equations detailed earlier. In general, $Y_{i}=\left[Y_{i 1}, Y_{i 2}, \ldots, Y_{i T}\right]^{\prime}$,

Let $X_{i}$ be the independent variables of the three equilibrium equations. In general, $X_{i}=\left[X_{i 1}, X_{i 2}, \ldots, X_{i T}\right]^{\prime}$

and $\varepsilon_{i}=\left[\varepsilon_{i 1}, \varepsilon_{i 2}, \ldots, \varepsilon_{i T}\right]$ 'are the respective error terms, and the stacked $N$ equation ( $T$ observations each) system is $Y=X \beta+\varepsilon$.

The reader should notice that not only the intercept but also the slope terms of the estimated parameters are different across individuals. The error structure of the model is summarized as follows:

- $\quad E(\varepsilon)=0$

- $E\left(X^{\prime} \varepsilon\right)=0$

- $\quad E\left(\varepsilon \varepsilon^{\prime}\right)=\Sigma \otimes \mathrm{I}$, where $\Sigma=\left[\sigma_{i j}, i, j=1,2, \ldots N\right]$ is the $N \times N$ variance-covariance matrix and I is a $T \times T$ identity matrix. Notice that contemporary correlation across individuals is assumed although there is no time serial correlation. The error structure of this model is different from that of the random effects model described previously.

The model is estimated using techniques for systems of regression equations.

Denote $b$ and $S$ as the estimated $\beta$ and $\Sigma$, respectively. Then,

$b=\left[X^{\prime}\left(S^{-1} \otimes I\right) X\right]^{-1} X^{\prime}\left(S^{-1} \otimes I\right) Y$

$\operatorname{Var}(b)=\left[X^{\prime}\left(S^{-1} \otimes I\right) X\right]^{-1}$,

and $S=e e^{1 / T}$

where $e=Y-X b$ is the estimated error $\varepsilon$. 
Appendix 3: Rank of Province's Group by Per Capita Social Output in 1980 (lowest $=1$ )

\begin{tabular}{|c|c|}
\hline Rank of regional dummies of per capita social output & Province \\
\hline 1 & Anhui \\
\hline 1 & Guangxi \\
\hline 1 & Guizhou \\
\hline 1 & Yunnan \\
\hline 2 & Fujian \\
\hline 2 & Jiangxi \\
\hline 2 & Henan \\
\hline 2 & Sichuan \\
\hline 3 & Inner Mongolia \\
\hline 3 & Hunan \\
\hline 3 & Shaanxi \\
\hline 3 & Gansu \\
\hline 4 & Shanxi \\
\hline 4 & Shandong \\
\hline 4 & Ningxia \\
\hline 4 & Xinjiang \\
\hline 5 & Hebei \\
\hline 5 & Hubei \\
\hline 5 & Guangdong \\
\hline 5 & Qinghai \\
\hline 6 & Jilin \\
\hline 6 & Heilongjiang \\
\hline 6 & Jiangsu \\
\hline 6 & Zhejiang \\
\hline 7 & Beijing \\
\hline 7 & Tianjing \\
\hline 7 & Liaoning \\
\hline 7 & Shanghai \\
\hline
\end{tabular}


Appendix 4: Summary of Variables

\begin{tabular}{|c|c|c|c|c|c|}
\hline Variable & Total No. & $M$ & $S D$ & Min & Max \\
\hline $\ln ($ non-hukou rural-urban migrant labor) (person ) & 140 & -0.74 & 3.28 & -4.61 & 4.08 \\
\hline \% of production team in Household Responsibility System(HRS) & 140 & 0.6 & 0.41 & 0 & 1 \\
\hline $\ln ($ agricultural population sales to nonagricultural population $)(1,000$ yuan; $1980=100)$ & 139 & 12.5 & 0.99 & 8.29 & 14.32 \\
\hline $\ln ($ value of crop output at 1980 price $)(1,000$ yuan $)$ & 140 & 14.85 & 1.08 & 12.38 & 16.62 \\
\hline Government procurement price & 140 & 394.03 & 4.86 & 385.77 & 398.48 \\
\hline $\ln ($ labor $\times 3$-year moving average of crop share $)$ & 140 & 8.04 & 1.22 & 5.41 & 9.92 \\
\hline $\ln ($ agricultural No. of dependents per workforce in household) & 134 & 0.92 & 0.89 & 0.36 & 5.45 \\
\hline $\ln ($ agricultural population $)(1,000$ pers ons $)$ & 140 & 9.94 & 0.97 & 7.94 & 11.38 \\
\hline $\ln ($ chemical fertilizer input $)(1,000$ ton $)$ & 140 & 7.31 & 1.1 & 4.82 & 9.06 \\
\hline $\ln ($ city average consumption $)(1,000$ yuan; $1980=100)$ & 133 & -0.75 & 0.64 & -1.1 & 6.37 \\
\hline $\ln ($ city consumer price index $)(1980=100)$ & 140 & 4.64 & 0.03 & 4.61 & 4.74 \\
\hline $\ln ($ cultivated land $)(1,000 \mathrm{mu})$ & 140 & 10.58 & 0.89 & 8.57 & 11.79 \\
\hline $\ln$ (nonagricultural population) (1,000 persons) & 140 & 8.55 & 0.7 & 5.48 & 9.58 \\
\hline $\ln ($ agricultural market price index $)(1980=100)$ & 140 & 4.69 & 0.08 & 4.55 & 4.89 \\
\hline $\ln ($ tractors and draft animals $)(1,000 \mathrm{hp})$ & 140 & 7.83 & 0.69 & 6.44 & 9.14 \\
\hline Multiple cropping index & 140 & 1.52 & 0.48 & 0.86 & 2.55 \\
\hline$\%$ of total area sown in nongrain crops & 140 & 0.21 & 0.09 & 0.1 & 0.91 \\
\hline $\ln ($ social total output $)(1,000$ yuan; $1980=100)$ & 140 & 17.16 & 0.84 & 14.81 & 18.58 \\
\hline $\ln ($ state-owned industry output) $(1,000$ yuan; $1980=100)$ & 138 & 16.26 & 0.9 & 13.8 & 17.95 \\
\hline $\ln ($ light indus trial amount $)(1,000$ yuan; $1980=100)$ & 131 & 15.58 & 2.26 & -6.91 & 17.58 \\
\hline $\ln ($ heavy industrial output $)(1,000$ yuan; $1980=100)$ & 131 & 15.75 & 2.19 & -6.91 & 17.51 \\
\hline $\ln ($ commercial industrial output $)(1,000$ yuan; $1980=100)$ & 140 & 14.38 & 0.83 & 11.95 & 15.9 \\
\hline $\ln ($ township collective industry output $)(1,000$ yuan; $1980=100)$ & 140 & 13.33 & 1.36 & 9.9 & 16.44 \\
\hline $\ln$ (village-owned collective industrial output) $(1,000$ yuan; $1980=100)$ & 136 & 13.62 & 1.01 & 10.62 & 15.98 \\
\hline $\ln ($ urban Individual labor sales amount $)(1,000$ yuan; $1980=100)$ & 138 & 11.99 & 1.64 & 6.91 & 14.97 \\
\hline Year $(1982=82)$ & 140 & 82 & 1.42 & 80 & 84 \\
\hline
\end{tabular}


Table 1: Historical Data for Variables of Interest (from other sources), 1978-84

\begin{tabular}{|c|c|c|c|c|c|c|c|}
\hline & Year & & & & & & \\
\hline Variable & 1978 & 1979 & 1980 & 1981 & 1982 & 1983 & 1984 \\
\hline No. of rural collectives $(, 000)$ & 1524 & 1480 & 1425 & 1338 & 1362 & 1346 & 6065 \\
\hline No. of rural collectives' employees $(, 000)$ & 28266 & 29093 & 29997 & 29696 & 31129 & 32346 & 52081 \\
\hline Average HRS, $\%$ & 0 & 0 & 0 & 38.6 & 69.2 & 93.6 & 97.4 \\
\hline Rural sales to urban population $(, 000)$ & 26620 & 38850 & 63760 & 88850 & 109160 & 133420 & 169500 \\
\hline No. of Intra-provincial Non-hukou Rural-city Migrant $(, 000)$ & 0 & 0 & 0 & 0 & 128 & 176 & 344 \\
\hline
\end{tabular}

\section{Note 1: For detailed descriptions, please see Appendix 1.}

Note 2: Data for 1978-83 covers only village and township enterprises; data for other years covers village, township, and town enterprises.

Note 3: the China's 1\% Population Sample Survey (1987) is the first Census that records the non-hukou migrant information from 1982 to 1986.

Sources: Liang et al. (2002, p. 2181) for TVEs and data on their employees; Lin (1992) for HRS data;

the 5\% random sample of China's 1\% Population Sample Survey (1987) for the number of intraprovincial non-hukou rural-urban migrants;

Hsueh et al. (1993) for rural sales to the urban population

Interpretation of table: Row 1 shows slow growth of rural collectives from 1978 to 1983 . Row 2 shows the low labor absorption rate of rural enterprises.

Row 3 shows the average provincial HRS ratio, Columns 4 and 5 show impressive growth of the respective variables.

The last row shows a doubling in the size of non-hukou rural-urban migration, during 1982-84, while their numbers are assumed to be zero since no nationallevel data is available. 
Table 2: A Seemingly Uncorrelated Estimation (SURE) of Agricultural Growth in China (1980-84)

\begin{tabular}{|c|c|c|c|c|c|c|}
\hline Variable & $(1$ & & $(2$ & & $(3$ & \\
\hline $\ln$ (value of crop output at 1980 price) $(1,000$ yuan) & Coefficient & $S E$ & Coefficient & $S E$ & Coefficient & $S E$ \\
\hline$\%$ of production team in HRS in the province & $0.20 * * *$ & 0.04 & $0.18 * * *$ & 0.04 & $0.19 * * *$ & 0.04 \\
\hline $\ln ($ cultivated land $)(1,000 \mathrm{mu})$ & $0.56 * * *$ & 0.06 & $0.49 * * *$ & 0.06 & $0.49 * * *$ & 0.06 \\
\hline $\ln ($ labor $\times 3$-year moving average of crop share $)$ & $0.11 * * *$ & 0.05 & $0.16 * * *$ & 0.05 & $0.20 * * *$ & 0.05 \\
\hline $\ln ($ tractors and draft animals $)(1,000 \mathrm{hp})$ & $0.16 * * *$ & 0.07 & $0.23 * * *$ & 0.07 & $0.27 * * *$ & 0.07 \\
\hline $\ln ($ chemical fertilizer input $)(1,000$ ton $)$ & $0.32 * *$ & 0.04 & $0.29 * * *$ & 0.04 & $0.23 * * *$ & 0.05 \\
\hline Multiple cropping index & $0.50 * * *$ & 0.05 & $0.49 * * *$ & 0.05 & $0.52 * * *$ & 0.05 \\
\hline Constant & $4.96 * * *$ & 1.07 & $4.83 * * *$ & 1.11 & $4.64 * * *$ & 1.1 \\
\hline No. of obs ervations & 130 & & 123 & & 119 & \\
\hline No. of parameters & 13 & & 13 & & 13 & \\
\hline Residual mean square error & 0.13 & & 0.13 & & 0.13 & \\
\hline$R^{2}$ & 0.99 & & 0.99 & & 0.99 & \\
\hline$F$ stat & 671.08 & & 657.44 & & 685.97 & \\
\hline$p$ value & 0 & & 0 & & 0 & \\
\hline
\end{tabular}

The dependent variable is $\ln ($ value of crop output). Column 1, 2, 3 shows, respectively, "Aggregated Social output," "SOE, Collectives, Individual labor output," and "Disaggregated Industrial Outputs," the SURE estimation results under three reduced form urban demand functions of non-hukou migration growth equation as specified at the section of model specification." All models include average agricultural procurement prices and per capita social output provincial groups as panel dummies as fixed effects. $* * * p<.01 ; * * p<.05 ;{ }^{*} p<.10$.

Interpretation of table: This is an estimation of the Cobb-Douglas production function. It is also the first equation of the three in the seemingly uncorrelated regression (hereafter, SURE) makes use of provincial data from the 1980-84 period. The table shows, first, that the percentage of HRS contributes to agricultural growth and, second, that the Wald test confirms the assumption that the production function is homogenous to degree 1. 
Table 3: (SURE) Estimation of Urban Agricultural Product Market Growth

\begin{tabular}{|c|c|c|c|c|c|c|}
\hline Variable & $(1$ & & $(2$ & & $(3$ & \\
\hline $\ln ($ agricultural population sales to nonagricultural population $(1,000$ yuan; $1980=100)$ & Coefficient & $S E$. & Coefficient & $S E$ & Coefficient & $S E$ \\
\hline$\%$ of production team in HRS in the province & $0.22 * *$ & 0.11 & $0.25 * *$ & 0.11 & $0.32 * * *$ & 0.11 \\
\hline $\ln ($ agricultural population) (1,000 persons $)$ & $0.71 * * *$ & 0.07 & $0.75 * * *$ & 0.06 & $0.75 * * *$ & 0.06 \\
\hline $\ln$ (agricultural hous ehold dependents) (1,000 pers ons) & -0.02 & 0.03 & -0.03 & 0.03 & -0.03 & 0.03 \\
\hline Multiple cropping index & $0.33 * * *$ & 0.07 & $0.27 * * *$ & 0.07 & $0.25 * * *$ & 0.07 \\
\hline $\ln ($ agricultural market price index) $(1980=100)$ & -0.52 & 0.51 & -0.42 & 0.48 & -0.63 & 0.51 \\
\hline$\%$ of total area sown in nongrain crops & -0.08 & 0.3 & 0.23 & 0.29 & 0.41 & 0.3 \\
\hline $\ln$ (nonagricultural population) (1,000 persons) & $0.14 * *$ & 0.07 & 0.08 & 0.07 & 0.09 & 0.07 \\
\hline $\ln ($ city average consumption $)(1,000$ yuan, $1980=100)$ & 0.05 & 0.04 & 0.04 & 0.04 & 0.04 & 0.04 \\
\hline $\ln ($ city consumer price index $)(1980=100)$ & $9.59 * * *$ & 1.45 & $8.80 * * *$ & 1.42 & $8.29 * * *$ & 1.47 \\
\hline Constant & $-39.29 * * *$ & 6.97 & $-37.08 * * *$ & 6.97 & $-33.63 * * *$ & 7.25 \\
\hline No. of obs ervations & 130 & & 123 & & 119 & \\
\hline No. of parameters & 16 & & 16 & & 16 & \\
\hline Residual mean square error & 0.27 & & 0.26 & & 0.26 & \\
\hline$R^{2}$ & 0.92 & & 0.92 & & 0.92 & \\
\hline$F$ stat & 84.58 & & 80.91 & & 79.36 & \\
\hline$p$ value & 0 & & 0 & & 0 & \\
\hline
\end{tabular}

The dependent variable is $\ln$ (agricultural population sales to nonagricultural population). Column 1,2,3 shows, respectively, "Aggregated Social output," "SOE, Collectives, Individual labor output," and "Disaggregated Industrial Outputs," the SURE estimation results under three reduced form urban demand functions of non-hukou migration growth equation as specified at the section of model specification." All models include average agricultural procurement prices and per capita social output provincial groups as panel dummies as fixed effects. $* * * p<.01 ; * * p<.05 ;{ }^{*} p<.10$.

Interpretation of table: This is the second equation of the seemingly unrelated regression. This regression shows the growth of informal urban agricultural product urban agricultural product market sales by $\ln$ (agricultural population sales to nonagricultural population). Column 1, 2, 3 shows, respectively, "Aggregated Social output," "SOE, Collectives, Individual labor output," and "Disaggregated Industrial Outputs," the SURE estimation results under three reduced form urban demand functions of non-hukou migration growth equation as specified at the section of model specification." I find that the growth of the urban agricultural product market sales is pushed up by the growth of HRS and pulled down by the city consumer price index. 
Table 4: (SURE) Estimation of the Intraprovincial Non-hukou Rural-urban Labor Migration Growth

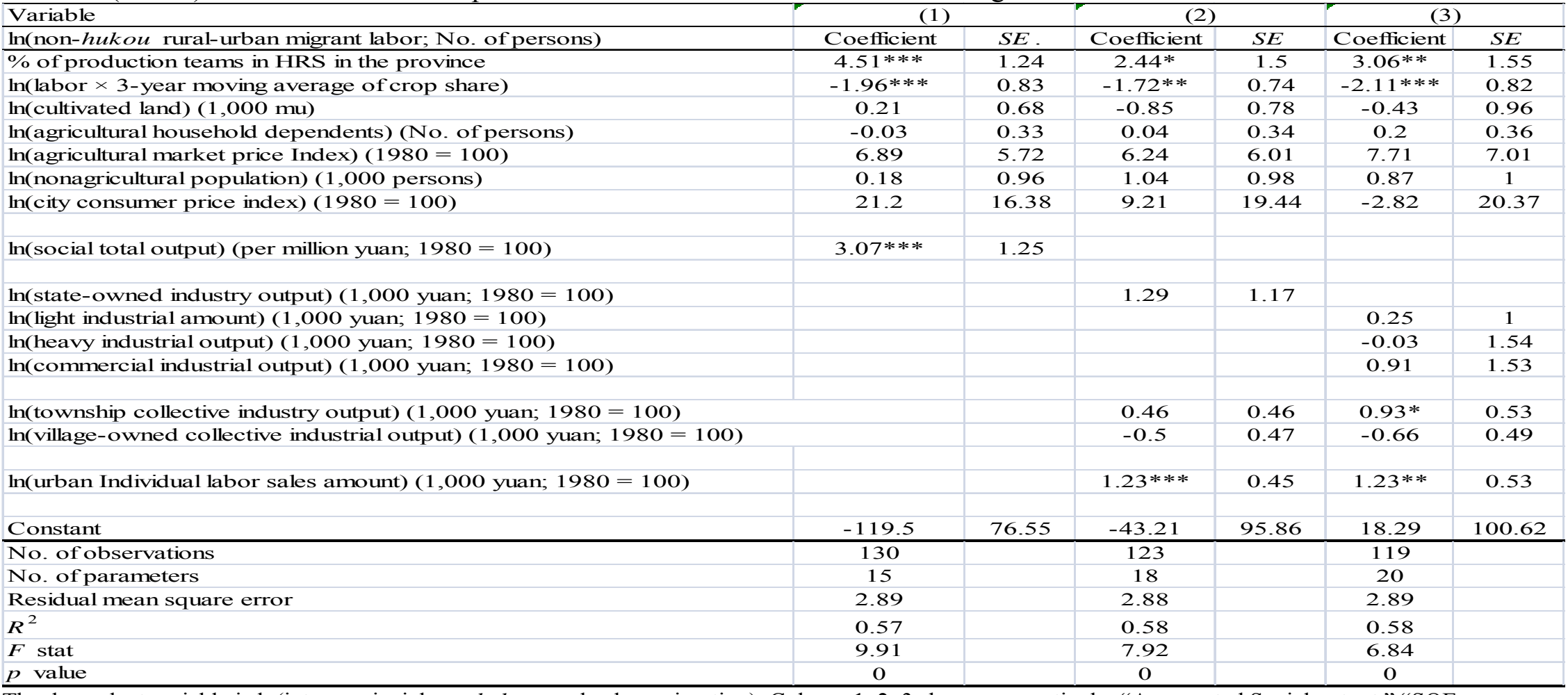

The dependent variable is $\ln ($ intraprovincial non-hukou rural-urban migration). Column 1, 2, 3 shows, respectively, "Aggregated Social output," "SOE,

Collectives, Individual labor output," and "Disaggregated Industrial Outputs," the SURE estimation results under three reduced form urban demand functions of non-hukou migration growth equation as specified at the section of model specification." All models includes average agricultural procurement prices and per capita social output provincial groups as panel dummies as fixed effects***p $<.01 ; * * p<.05 ; * \mathrm{p}<.10$.

Interpretation of the table: This is the last equation of the seemingly unrelated regression that estimates the growth of informal rural-urban migrant labor. The dependent variable is $\ln$ (intraprovincial non-hukou rural-urban migration). Column 1,2,3 shows, respectively, "Aggregated Social output," "SOE, Collectives, Individual labor output," and "Disaggregated Industrial Outputs," the SURE estimation results under three reduced form urban demand functions of non-hukou migration growth equation as specified at the section of model specification." The table shows that the growth of non-hukou rural-urban migration is "pushed" up by the growth of HRS and pulled down by the $\ln$ (individual labor sales amount). 
Table 5: Rank Order of Intraprovincial Non-hukou Migrants and Urban Individual Labor

\begin{tabular}{|c|c|c|}
\hline Province & No. of intraprovincial non-hukou migrants & No. of urban individual laborers \\
\hline Guangdong & 1 & 1 \\
\hline Sichuan & 2 & 2 \\
\hline Heilongjiang & 3 & 4 \\
\hline Xinjiang & 4 & 6 \\
\hline Anhui & 5 & 5 \\
\hline Jilin & 6 & 9 \\
\hline Hubei & 7 & 8 \\
\hline Inner Mongolia & 8 & 16 \\
\hline Liaoning & 9 & 7 \\
\hline Zhejiang & 10 & 18 \\
\hline Gansu & 11 & 15 \\
\hline Beijing & 12 & 27 \\
\hline Shanxi & 13 & 23 \\
\hline Jiangs u & 14 & 17 \\
\hline Shandong & 15 & 13 \\
\hline Shanghai & 16 & 24 \\
\hline Hebei & 17 & 21 \\
\hline Guangxi & 18 & 10 \\
\hline Hunan & 19 & 11 \\
\hline Yunnan & 20 & 20 \\
\hline Fujian & 21 & 19 \\
\hline Guizhou & 22 & 12 \\
\hline Jiangxi & 23 & 14 \\
\hline Shaanxi & 24 & 22 \\
\hline Henan & 25 & 3 \\
\hline Ningxia & 26 & 28 \\
\hline Qinghai & 27 & 26 \\
\hline Tianjing & 28 & 25 \\
\hline \multicolumn{2}{|c|}{ Rank correlation coefficient to No. of intraprovincial migrants } & 0.62 \\
\hline
\end{tabular}

Data source: No. of intraprovincial non-hukou migrants is those who migrate within 5 years in the $5 \%$ sample of $1 \% 1987$ China's Census.

No. of individual laborers is from Hsueh et al. (1993).

Interpretation of the table: This table validates the correlation between intraprovincial non-hukou migration and urban labor market developing. The results show that the number of urban individual laborers as the proxy for urban labor market development is highly related to the non-hukou migration (within 5 years of the Census). Eight of the provinces in the top 10 in no. of urban individual laborers are also the top 10 intraprovincial non-hukou migrant provinces, and the rank correlation between the intraprovincial non-hukou migration column and the no. of urban individual laborers column is extremely high at .62. 
Figure 1: Expected value of non-hukou rural-urban migration (1980-84)

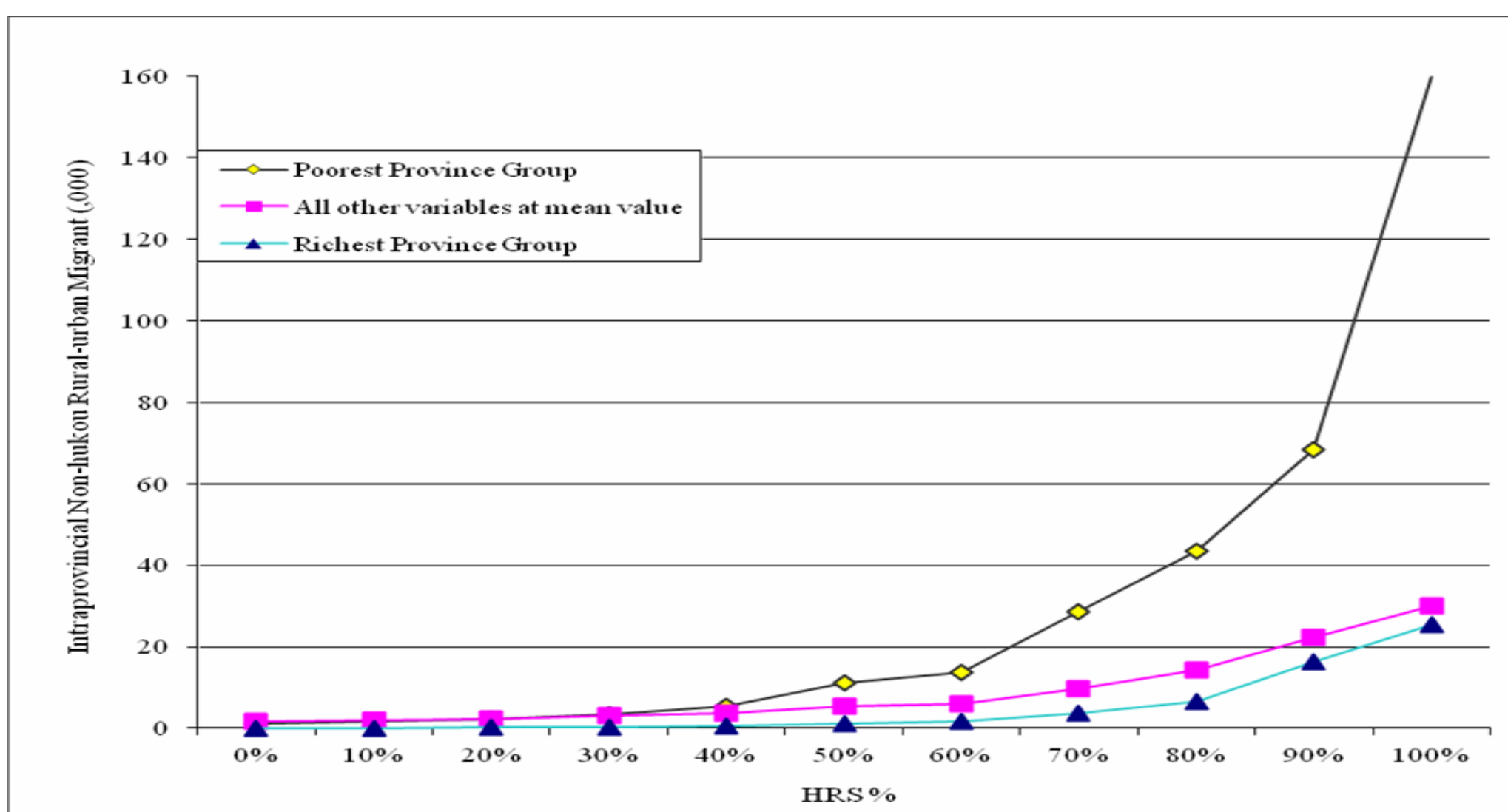

Interpretation of the figure: This shows a Monte Carlo study of the expected value and its confidence interval (CI) of individual labor growth during the 1980-84 period. Holding other variables at their mean value, when \% of HRS changes from 0 to 100, the graph shows that the expected provincial average non-hukou migration is 25,500 for the richest provincial group, while the poorest provincial group jumps to 160,000 non-hukou migrants on average from 1980 to 1984 . 
Figure 2: A comparison of the expected rural collectives' absorption of urban individual laborers (1980-84)

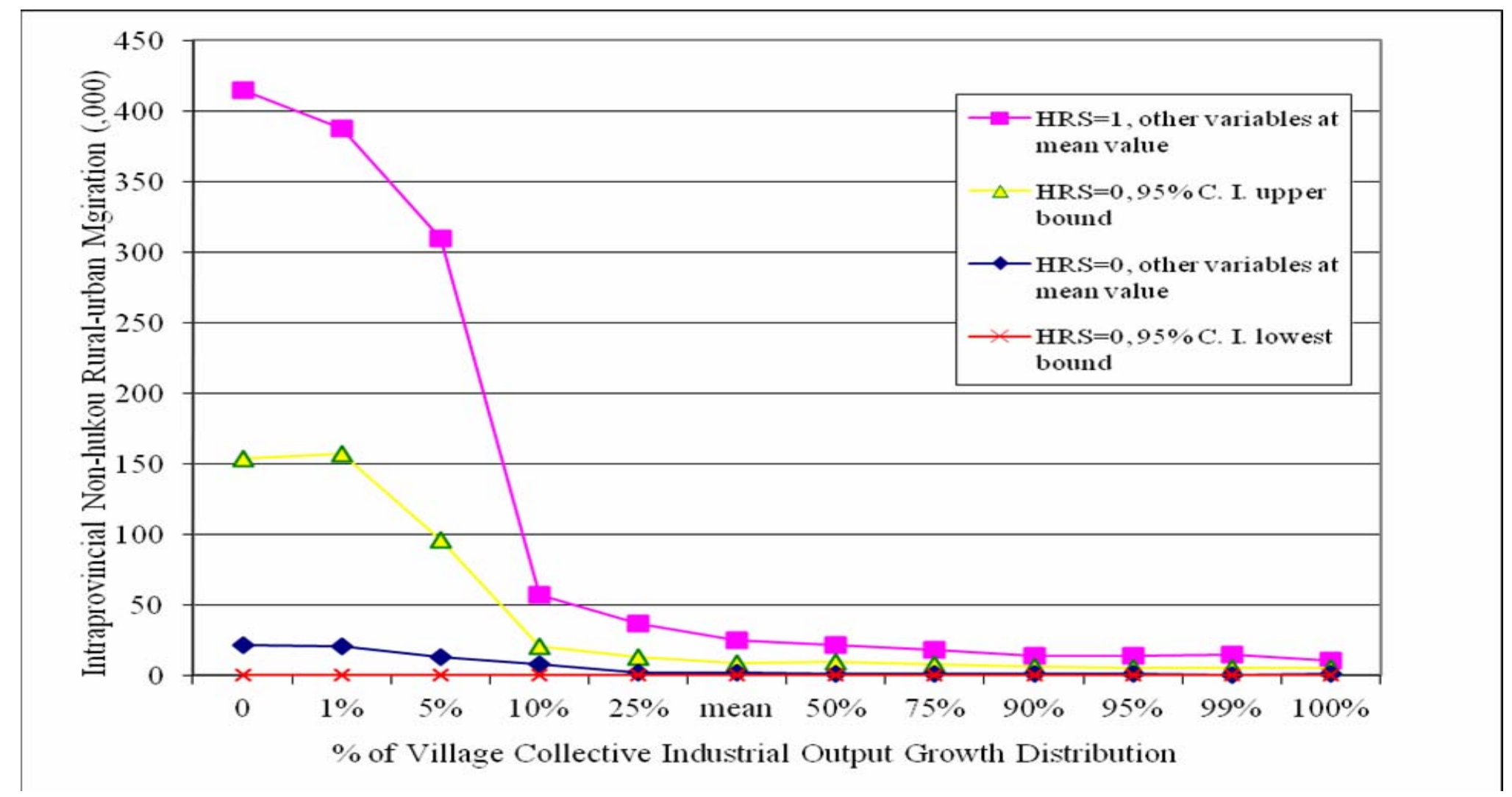

Interpretation of the figure: This Monte Carlo study compares different of the expected urban labor absorption of the rural industrialization when HRS $=0$ and $\mathrm{HRS}=1$ (1980-84) while controlling other variables at mean value and assuming the rural industrialization policy is significant. All the estimated number of nonhukou migration trends is negatively related to the growth of rural industrialization. In particular, the upper line show the non-hukou migration number when $\mathrm{HRS}=1$ is about the upper bound of the $95 \%$ confident interval of the non-hukou migration curve when HRS $=0$. That means the HRS has been effectively promoted the rural-urban non-hukou migration and has overcome the negative effects of Township strategy which utilized the rural industrialization to absorb rural laborers. 